Emmanouilidis, E. C. \& Economides, A. A. ICT usage by Greek accountants. International Journal of Information Systems in the Service Sector. IGI-Global. ISSN: 1935-5688; EISSN: 1935-5696. Accepted.

\title{
ICT Usage by Greek Accountants
}

Efstratios C. Emmanouilidis graduated from the Hellenic Officers Military Academy, in 1996. In 2002, he graduated from the School of Computer Programmers of the Hellenic Army. Holding a Hellenic Army Fellowship, he received the M.Sc. degree in Information Systems from the University of Macedonia, Thessaloniki, Greece, in 2005. In 2006, he graduated from The School of Research and Informatics Officers of the Hellenic Army. Currently, he is a military Officer at the rank of Captain and serves in Research and Informatics Corps of Hellenic Army. His research interests include statistics analysis and programming.

Anastasios A. Economides (*) received the Dipl.Eng. degree in electrical engineering from the Aristotle University of Thessaloniki, in 1984. Holding a Fulbright and a Greek State Fellowship, he received the M.Sc. and the Ph.D. degrees in computer engineering from the University of Southern California, Los Angeles, in 1987 and 1990, respectively. At graduation, he received the Outstanding Academic Achievement Award from the University of Southern California. Currently, he is an Associate Professor and Chairman of the Information Systems Department at the University of Macedonia, Thessaloniki, Greece. He is the director of CONTA (COmputer Networks and Telematics Applications) Laboratory. His research interests include techno-economics of networks and eservices. He has published over one hundred fifty peer-reviewed papers. He has been the plenary speaker in two International Conferences. He has served on the editorial board of several International Journals, on the program committee of many International Conferences, and as a reviewer for many International Journals and Conferences.

Efstratios C. Emmanouilidis

University of Macedonia

Department of Information Systems

Egnatia 156,

54006 Thessaloniki, GREECE

Tel: 30-2310-891799

emm_stra@yahoo.com

Anastasios A. Economides

University of Macedonia

Departments of Information Systems and Economic Sciences

Egnatia 156,

54006 Thessaloniki, GREECE

Tel: 30-2310-891799

economid@uom.gr 


\title{
ICT Usage by Greek Accountants
}

\author{
Efstratios C. Emmanouilidis and Anastasios A. Economides \\ University of Macedonia, GREECE
}

\begin{abstract}
This study investigates the use of Information and Communication Technologies (ICT) by Greek accountants' offices. Initially, a comprehensive questionnaire was developed. It contains 35 questions with multiple answers and 2 open questions tailored to the accountants. The questionnaire was answered by 100 accountants' offices in a Greek county. The findings present their current ICT infrastructure, and their usage of ICT and accounting e-services. Greek accounting offices have made improvements in adopting new technology in their everyday work. All of them use email, antivirus software and the Web. Most of them submit VAT (Value Aided Tax), Taxation Statements and APS (Analytical Periodic Statement) via Internet. However, most of them are not cautious about backing up their data daily, they do not create electronic files for all their documents, they do not update their software via Internet, and they do not use advanced software applications. Finally, they expect that the Government and the Accountants' Chamber should finance their ICT infrastructure.
\end{abstract}

Keywords: accountants; computer usage; e-accounting; e-finance; e-government; e-services; etaxation; ICT infrastructure; Inland Revenue Services; Internet usage; online tax filling.

\section{INTRODUCTION}

The profession of accountancy has experienced unprecedented change during the last 20 years. It has been moved from paperbased to PC-based, and the Internet has become prevailing tendency. Similarly to other professions in the service sector (Levy et al., 2009; Lexhagen, 2009), the recent technological developments have given the opportunity to accountants to incorporate information systems in their profession. They use the PC, at a large extent, for customers' book keeping and liquidation of income tax statement. They spend a lot of time to process and produce many documents (Bhansali, 2006a). Also, they use the Internet widely for submitting the tax statements to the government (Anderson et al., 2005; Garen, 2006). The recent advances in e-government (Chatzopoulos \& Economides, 2009; Economides \& Terzis, 2008; Terpsiadou \& Economides, 2009) have pushed accountants to follow. Furthermore, over 2.000 accounting firms have Web sites registered with "The List of CPA Firms Directory” (Roxas at al., 2000).

Many software packages are available to help accountants in book keeping. However, many of these software packages become quite complicated and present problems of interoperability and usability, among others. Human - computer interface issues are extremely important for online service applications (Pinhanez, 2009). In parallel, many accountants lack the time or the patience to learn the skills needed to take full advantage of these advances. Even worse, the technology continues to move forward, getting more complicated and thus widening the gap between potential and actual use (Zarowin, 2004).

While the technology's impact on the accountants' profession has been considerable, there are many more developments to come. So, accountants must be technologically proactive (Johnston, 2005). During the next years, the profession of accountancy will face probably unexpected new challenges (Bhansali, 2006b).

The aim of this study is to investigate the level of ICT usage by the accountants' offices in a Greek county. In the next section, previous studies on these issues are presented. Then the methodology is described. The presentation of the results follows. Finally, conclusions are drawn and future research is suggested.

\section{PREVIOUS RESEARCH}

There are not many previous studies on the use of ICT by accountants' offices. Some detailed studies were conducted by the American 
Institute of Certified Public Accountants (CPA).

Gallun et al. (1993) distinguished between small or large public CPA (Certified Public Accountants) and accountants in large enterprises (industry accountants) in USA. They found that large accountants' offices used more LANs (Local Area Networks) than small ones. Also, most accountants did not appear to worry very much about viruses and other security issues. Most of them used laser printers along with the essential dot matrix, and the most popular brand was HewlettPackard. Finally, a small percentage used portable printers.

Khanil et al. (1994) showed that $23 \%$ of enterprises in USA supplemented electronically all forms (e.g. liquidation of income tax statement), and $15 \%$ of them planned to do it in the future. Regarding security, 31\% faced virus problems. Also, 37\% used antivirus program, and from them 68\% used Norton. Regarding backup, 83\% backed up their data, and from them $80 \%$ did this daily while $16 \%$ weekly. E-mail was used by $39 \%$ of the offices.

Prawitt et al. (1997) distinguished USA accountants in the following categories: 1) in big accountant offices (Big 6 - national), 2) in intermediate (regional) offices, 3) in small offices (local and offices of individual), 4) in organisations (business and non-profit), 5) in schools (academic), and 6) in governmental organisations. The most popular operating system was the Microsoft Windows. All accountants in the first two categories used networks. The most popular application office suite was Microsoft Office (Word, Excel, Access, and PowerPoint). All accountants used applications for managing their contacts and timetables, and the most popular application was ACT! by Sage, while the small usage of Microsoft Outlook was interesting.

Bush (2000) found that 96\% of USA accountants had access to the Internet. More than half of them reported that they "surf" every day. Also, $65 \%$ of the men and $47 \%$ of the women reported that Internet created more opportunities for them. Finally, $47 \%$ of them expected an increase in the Internet usage for accounting research.

Anders et al. (2004) found that the accountants of New York were absolutely satisfied with the programs of accountancy that they used for third consecutive year. Also, it was observed an increase in the creation of web pages by accountants aiming at the satisfaction of their customers.

Zarowin (2006) found that a lot of accountants' offices of all sizes transformed their offices to become electronic offices. In 2003 , only $38 \%$ of them prepared invoices electronically directly using PCs. In 2005, the percentage increased to $46 \%$. In $2003,64 \%$ of them used internal local networks (Intranets) for the storage and process of customer's data. In 2005, the percentage increased to $72 \%$. Finally, the number of accountants' offices that stored their customers' documents only in the computer without printing them (electronic paperless office) showed an enormous increase of $103 \%$ from 2003 to 2005.

In another area of research regarding the usage and development of Web pages for advertising by companies in European Union during 2000-2003 showed an increase by 19\% (Voiculescu, 2003). Advertising was the main reason for using and developing web pages (59\%). It is remarkable that the income acquisition as a reason was at the third place (11\%) behind the customer's service (26\%).

Gullkvist and Ylinen (2005) found that the most important reasons for the development of e-accounting systems by Finnish accounting agencies were the following: more efficient use of time resources, higher internal performance, availability of accounting information, and perceived requirements from authorities. Lack of time can clearly been seen as one of the key obstacles delaying the adoption of the e-accounting systems among SMEs.

The accountancy profession is feeling the strain of increased responsibility, away from the traditional roles that accountants were trained for (Mintel, 2005). Although the triggering factors for stress and increasing staff turnover are high, little is currently being done to improve the situation. A resounding $84 \%$ of US companies said that their accounting department was leading the compliance initiatives in the company. The same $84 \%$ stated that increasing compliance requirements have put them under greater pressure due to the increase in scope and volume of their work, and yet $88 \%$ were still manually rekeying data into spreadsheets for reporting and analysis (Mintel, 2005).

Although many Inland Revenue Services support electronic tax filling (Economides \& Terzis, 2008), still many accountants continue not using these new electronic services. Each one of these previous studies investigated only 
a specific area of ICT usage by accountants. For example, one study examined the types of networking technologies adopted; another study examined the types of software used; while another study examined the accountants' websites. So, there is the need to develop a comprehensive survey to capture a complete view of the ICT usage by accountants. Furthermore, most studies were investigated the accountants in USA. So, there is the need to also investigate the ICT usage by accountants in other countries too.

\section{METHODOLOGY}

Based on the OECD (Organization for Economic Co-operation and Development) (2002) model, on our experience on surveying other services' areas, on opinions of accountants after extensive discussions with them, and on the previous studies presented above, we developed a comprehensive questionnaire to find out the usage of ICT by accountants. Specially, fruitful discussions with members and officials of a local Accountants' Club helped us in finalizing the questionnaire.

We were interested in finding out what ICT infrastructure was owned and used by the accountants' offices in a Greek province. Also, we investigated what kind of accountantspecific software and e-government services the accountants were using. We also wanted to identify the problems that they faced in their daily accounting work regarding to the ICT usage. Then, suggestions to the Greek government and the Greek Accountants' Chamber could be made.

The questionnaire contains 30 closed type questions with multiple choice answers and two open type questions. We classified the questions into four categories:

1) General information about the accountants' enterprises (5 questions),

2) ICT Infrastructure of the enterprise (18 questions),

3) Internet usage and Web presence (4 questions), and

4) Accounting software applications and services (8 closed +2 open questions).

In the survey's region, there exist 120 Accountants' Offices. The research was carried out at 100 Accountants' Offices (private as well as belonging to enterprises) in this Greek County, using the method of interview at each office. The rest 20 offices did not participate due to their lack of available time. We must point out that we faced several obstacles in trying to interview the accountants due to their limited spare time.

We selected the specific survey's region because we have personal relationships with many accountants in this region. So, we expected that they will offer their time to answer our questionnaire. During 2006-07, we visited personally 75 offices and spend some time to interview them. 25 offices were interviewed by phone. Next, we present the results.

\section{RESULTS}

\section{General information about the accountant enterprises}

Most accountants' offices (53) employed 4 to 9 persons, followed by offices (37) with less than 3 persons. There were also 10 offices employing more than 9 persons.

Almost all offices (98) were autonomous private offices, while 2 offices belonged in large enterprises. This was expected since most Greek Accountants work mainly as free professionals having their own private offices.

Most offices (63) were active in the profession for more than 15 years. Most of them (31) were active for 23 years. Only 13 offices were relatively new in the profession (less than 6 years)

\section{ICT Infrastructure}

As it was expected, all offices used Internet and e-mail, since they need to use the egovernment services of Inland Revenue Service. WAN (Wide Area Networks) were used by only 2 offices those that belong to large enterprises (Figure 1).

It is important that 63 offices set up LAN networks for better internal office operation. Considering the offices that have LANs, $21 \%$ of them employed 1-3 persons, $62 \%$ employed 4-9 persons, and $17 \%$ employed 10 or more persons. This shows that the use of networks in the small and medium-sized enterprises is also becoming a necessity.

The number of PCs was proportional to the number of personnel. In particular, 58 offices owned 4-10 PCs, and 42 offices owned 1-3 PCs. However, no office owned more than 10 PCs although 11 offices employed more than 10 persons. This happens because not all personnel were concurrently working on PCs. Some of them were occupied at exterior works 
(e.g., visiting the Inland Revenue Service, the Social Security Organization, and Banks).

Out of 63 offices that set up LAN networks, 21 offices used Client-Server technology and 42 offices used Peer-to-Peer (P2P) technology (Figure 2). This was expected for such small LANs since the P2P networks cost less and do not require specialised personnel for maintenance. It is also noteworthy, that among the rest 37 offices that did not set up any network infrastructure, 29 offices planned to set up one in the near future, while 8 did not.

Furthermore, 26 offices used separate file server for central storage of all their files (in both Client-Server and P2P networks), 4 offices used Print Server (only in Client-Server networks), 12 offices used Backup Server (only in Client-Server networks) and no office used Mail Server. Since most offices employed few employees, they usually met each other in person at the office. The 26 offices that used file server realised that they protect their important files by placing them centrally, and do not waste time in updating the same data on separate PCs.

It is also interesting that among the offices that used Client-Server, $10 \%$ offices owned 13 PCs (Figure 3). Also, among the offices that used P2P, 62\% offices owned 4-10 PCs. This may happen because the accountants were not fully aware of the different benefits offered by each one of these networking technologies. Usually, an office imitates others and decides to invest on something that others suggest. Naturally, the cost is also a very important factor in this choice. Instead of buying a new server, many small offices transformed an old PC to a File Server.

The offices that did not plan to set up a LAN were small offices with usually 1 PC and sometimes 2 or 3 PCs. Roughly half of the offices that planned to set up a LAN owned 110 PCs (Figure 4).

Only 34 offices owned laptops apart from PCs. This happens because some accountants were also working at their homes using laptops.

As it was expected, 92 offices owned Dot Matrix printers since printing is essential for their daily work, e.g. customers' books printing (Figure 5). It is interesting that 30 offices had black \& white Laser printers and 16 offices owned colour Laser printers. These offices were mainly large offices with many customers as well as the 2 offices that belonged to big enterprises. More than half of the offices owned new multi-machines (fax, Inkjet printer, scanner together) which is the most economical way for small offices. 42 offices owned old fax machines. The new offices preferred to buy multi-machines. 66 offices owned inkjet printers which are also the most economical printers for printing few pages. 7 offices owned separate scanners. Only 16 offices owned photo-copy machines. This mainly happened in big offices with many customers.

It was impressive to find out that all offices used antivirus programs, while hardly 76 offices used separate firewall programs apart from that included in Windows XP Operating System (Figure 6). Also, 12 offices used full data backup systems. These were mainly big offices and those that belong to big enterprises which had explicit backup policies. Due to the large cost of such technologies, the remainder offices did not use such technology. Instead, they used more economical ways of backing up their data. The offices that did not use a firewall program were mainly small offices with few PCs and they did not wish to purchase separate programs, since the firewall which is included in Windows XP is working well.

Regarding security problems faced by the offices during the previous year, 18 offices faced virus or spy-ware problems, 11 offices faced unauthorized access into their PCs, and 1 office faced a program exploitation problem (Figure 7). The main reason for these problems was that despite the fact that all offices were equipped with antivirus programs, they did not updated these programs daily or even they did not have them activated. The unauthorized access could be associated with the fact that most offices did not use password and user name to log in Windows.

79 offices backed up their critical data daily, 11 offices did this weekly, and 10 offices did this monthly (Figure 8). They claimed that the main reason for not backing up daily was the lack of time and their belief that it is not important to back up daily.

Regarding the media used for back up (Figure 9), most offices (86) backed up on the local disk (another partition or another file), 16 offices used a backup server, 8 offices used the old zip-drive and 29 offices used CD-DVD. 21 offices used more modern methods such as USB flash disk and external USB hard disk. Only 2 offices knew about and had a complete image backup of their hard disk. These 2 offices were small offices with less than 3 
persons, but these persons were young and familiar with new technology.

As it was expected, they used Microsoft's software for general use. They used Windows $\mathrm{XP}$ as Operating System, and the Microsoft Office 2000-2003 as Office Suite. Most companies did not know about open source software.

68 offices used password and user name for login Windows system. The remainder 32 offices were mainly small offices with few PCs, and they did not consider it essential.

Regarding the problems that they faced by the ICT introduction into their enterprises, 18 offices considered as a problem the lack of information and knowledge about ICT, 16 offices had problems with the terminology, and 13 offices were burned up by the timeconsuming procedures (Figure 10). However, it is interesting that most offices (58) did not face any particular problem, and 5 offices were not interested in any of these problems. This happens because most offices were staffed by accountants young in age who eagerly follow any new technological innovations.

Regarding the usage of VoIP (Voice over Internet Protocol) technology, only 4 offices had used Skype in the past (Figures 11 \& 12). Most offices declared that this technology is still unreliable and they will wait until it becomes perfect in order to use it again. 67 offices declared that they had not used it but they were intending to do so in the future, while 23 offices declared that they did not intend to use it at all. The reasons for not using VoIP were that this technology is still new, unreliable and there is no sufficient information about it. At that time, only 2 Greek telecommunications companies provided VoIP (Voice over Internet Protocol) in parallel with other services and they did not advertise it enough. 16 offices declared that they were not interested at all in this new technology.

Regarding to the degree of familiarization with ICT and their continuing training policy, most offices (58) maintained continuous training policy, and were very familiar with ICT (Figure 13). So, most accountants recognized the benefits of ICT. Internet explosion helped a lot in this. On the other hand, few offices (8) hesitated to use ICT. These were mainly old offices having elderly accountants who could not keep pace with the new technologies and simply used only the essential stuff for their daily work. 34 offices were very familiar with ICT but they did not have any training policy. This happens mainly in small offices with 1-2 persons.

Regarding their expectations from their Chamber (http://oe-e.gr, http://pol.org.gr) or the Government, 71 offices wished to be financed for purchasing or using new ICT products (Figure 14). This means that accountants were wiling to use the new technologies but they needed money to proceed in this.

\section{Internet usage and Web presence}

In this section, we present the results about the Internet use by accountants. Let mention that a Greek Accountant Office should have Internet connection in order to be connected to the Inland Revenue Service (TAXIS NETwww.taxisnet.gr). So, 43 offices used ISDN (Integrated Services Digital Network), while 53 offices already adopted the new ADSL (Asymmetric Digital Subscriber Line) technology (Figure 15). However, 4 offices still used simple PSTN (Public Switched Telephone Network) connections via modems. These are small offices of elderly accountants who did not wish to upgrade their infrastructure. No office used wireless or satellite connections.

More than half of the offices used ADSL connection due to the aggressive policy of the main Greek Telecommunication Company (OTE). Recently, OTE has dropped the cost of ADSL making it affordable for any office. Associating these results with their upgrading plans, we see that most of the 53 offices that planned to upgrade their Internet connection used ISDN. Accountants also embraced the ADSL technology because it was accessible economically and technically.

Only 3 offices developed a Web site. These Web sites were developed by external personnel and not by the office's personnel. Also, they were hosted in an ISP (Internet Service Provider) server. It makes sense for an accounting office to not exclusively employ ICT specialists and assign such work to an ICT specialist company. They believed that the main and only reason for developing a Web site was for advertising. However, they did not consider essential to be advertised in this way. This conclusion is also supported by the fact that only 5 offices planned to create Web pages in the near future.

As we have already mentioned, it is necessary for an accountant office to have Internet connection to deal with transactions 
with public services, e.g. with the Inland Revenue Service (www.taxisnet.gr). Consequently, all the offices answered that the main reason for using the Internet was for communicating with the public services and ministries (Figure 16). 34 offices considered also as a reason the e-banking in order to deal with the economic transactions of their customers. 58 offices were also interested in finding information on the Web.

They rated equally the various problems that affect their Internet usage (Figure 17). These problems were related to security, complicated technology, Web site cost, loosing time in surfing, communication costs, slow and unstable data communications. Most offices (47) considered them as serious problems, 37 offices considered them as fair problems and only 13 offices did not care about them. So, most accountants were hesitant about Internet.

\section{Accounting software applications and services}

In this section, we report on the use of accounting software and related services by the accountants.

The usual work of a Greek accountant is the book keeping of A and B categories. In the Greek market, there are software packages operating in a network environment useful for book keeping of A and B categories. These software packages can be used simultaneously by several persons depending on the licence. In 63 offices, such software packages were used by 2 or more persons in a network environment. In the remainder 37 offices, a single person used them. This happened mainly in small offices.

In Greece, all the enterprises are obliged to send the VAT (Value Added Tax) statement periodically (every quarter for A \& B categories) to Internal Revenue Service. According to the existing legislation, it is not obligatory for the accountants to send these statements electronically via TAXIS NET (www.taxisnet.gr) even if such possibility is provided. Most offices (82) sent periodically the VAT statement electronically exploiting these electronic services that are offered by the state. Few offices (18) used the traditional way of going in person to the Inland Revenue Service to deposit their statement.

While almost all of these software packages support data exchange with the MS Office, none office used this ability. This happens because either the accountants did not know this possibility or they did not need it.

Although these software packages could be upgraded via the Internet in real time (live update) most offices (61) did not download the new versions. This might happened due to that they were not familiarized with this process or they did not know the existence of this possibility. On the other hand, 26 offices checked for new versions once per month, and 13 offices did it daily.

Examining what types of printers they used to print out reports when using their software packages, 92 offices used all types of printers. 89 offices did this daily and 3 offices did it weekly. The remainder 8 offices, which are small offices, owned and used only one printer (Figure 18).

Next, we investigate the book keeping of C category. Large enterprises with large turnover need to keep C category books. So, this book keeping of $\mathrm{C}$ category is mainly done by large accountants' offices with a lot of experience. Regarding the simultaneous use of the software packages by 2 and more persons, we have the same results as in the book keeping of A \& B categories, i.e. the accountants used networking technology. So, 63 offices used this ability daily and 37 never. In these 37 offices there were also included offices which did not served customers of this C category.

All offices did not use the software's ability of connecting to MS Office. For C category book keeping, the accountants must frequently update all the elements of their software packages. So, regarding the upgrade via Internet in real time, 53 offices never did this, 13 offices did it monthly, 5 offices did it weekly, and 29 offices did it daily. Regarding the printing of work related to the $\mathrm{C}$ category book keeping, 66 offices with many such customers printed out daily. However, 28 offices did not printed anything relevant because they did not have such customers, 3 offices printed some times per month because they had 1-2 such customers, and 3 offices printed out some times per week (Figure 19).

Only 8 offices used CRM (Customer Relationship Management) systems daily while the remainder 92 offices did not know about CRM. These 8 offices were mainly large offices with many customers. Similarly, only 2 offices that belong to the big companies used ERP (Enterprise Resource Planning) systems daily (Figure 20). It is obvious that most offices did not need any ERP connectivity 
with the accounting software. Only large companies with specialized accountants section used ERP.

Regarding to payroll services in Greece, all the enterprises that pay personnel are obliged to send every month the APS (Analytic Periodical Statement) to the Organisation of Social Security (IKA). IKA offers multiple ways to help the accountants to do this. Currently, the two most popular methods are: i) create a compatible file using the payroll program and send it to IKA, and ii) type the elements in suitable forms on the Web site of IKA (http://www.ika.gr) and complete the sending of APS (Analytic Periodical Statement). The first method is used by 92 offices monthly (Figure 21). The second method is used by 71 offices monthly. 8 offices did not use any payroll software.

3 offices upgraded their payroll software online daily, 87 offices did it monthly and 10 offices never.

Concerning the electronic communication with banks or with other institutions of social insurance (as well as the exchange of electronic data), 79 (respectively 82) offices never did these, 10 (respectively 8) did these monthly, and 11 (respectively 10) did these daily (Figure 21).

97 offices used Windows-based accounting software while only 3 offices used the old DOS-based software. The Greek Accounting Software Companies helped a lot by adapting their products to the new technological innovations.

Figure 22 shows the specific accounting software programs used by the offices. UNION is used by 37 offices, while SINGULAR is used by 24 offices. EPSILONnet is a powerful program but it is more expensive than the others and it is used by 12 big companies.

However, the accountant offices fell behind the new ways of software upgrading. 79 offices upgraded their software via post (CD) (Figure 23). Although new technology is available to help them, many of the offices insisted on using the old way. 8 offices upgraded their software directly via Internet (live update) over a broadband Internet connection, and 34 offices upgraded it after downloading and installing the update file.

The accountants kept on informed about new developments in their profession via multiple means. 92 offices read periodical press, 53 offices read www.gus.gr, 37 offices read www.e-forologia.gr, 26 offices read the online e-magazine EPSILON7

(www.epsilonnetwork.gr/epsilon7), and 29 offices were informed by discussions in various forums (Figure 24). It is apparent that many accountants were informed not only via the traditional written press but also via Internet.

As we have already reported, many accountants used the new e-services provided by the Inland Revenue, TAXIS NET. Although it was not obligatory to send the VAT statements regarding the A and B Books categories via Internet, 92 offices did this. Also, 95 offices sent their customers' final Taxation Statement to TAXIS NET. So, the accountant offices realized the benefits of using the new online services that government provided (Figure 25).

Finally, the Greek accountants were not familiar with the new tendency of "paperless office" that prevails in the USA. Only 2 offices had started creating an electronic file for each of their customers by scanning the forms and storing them in e-files. Also, none of them could send to their customers their invoices in electronic form. Instead, they preferred to key the invoice's data in the corresponding software. They did not use these technologies because 76 offices did not consider them to be important, and 50 offices did not have much time for such work (Figure 26).

Finally, almost all offices considered that the following factors were very important for their software packages: convenience of learning and using it, reputation of software's company, live update ability, specifications and functions, customer support, user friendliness and online service (Figure 27).

\section{CONCLUSIONS}

The purpose of this study was to provide insights into the level of ICT usage by the accountants' offices in a Greek county.

The Greek state provided various egovernment services to accountants. This activated the accountants' offices to use and develop ICT infrastructure. Various Greek public organizations provide e-services. For example, the Ministry of Finance provides www.taxisnet.gr and the Ministry of Employment provides www.ika.gr. These egovernment services help accountant offices to save time and better serve their customers.

The findings from this survey showed that the accountants' offices in a Greek county kept 
pace with ICT technological innovations. For example, Internet was widely used by them. However, elderly accountants seemed to be more resistant in adopting the new technologies.

Briefly, the positive points were the following:

- Many (63) offices set up a LAN, and 29 of the rest planned to do it in the future. So, the accountants recognized the benefits of having a LAN in their enterprise. Software companies helped in this direction by providing the possibility of using their programs in a network environment without extra cost.

- All the offices had antivirus programs for their PCs.

- Few (18) offices faced viruses' problems during the last year.

- Many (58) offices did not face any problems in using ICT.

- Many (82) offices used the electronic submission of VAT (in Books A and B category) via the www.taxisnet.gr, something that it is not obligatory to be done.

The negative points were the following:

- Few (26) offices used separate file servers to keep on their data.

- Few (12) offices used complete backup systems for their data.

- Only 79 offices backed up their data daily.

- Very few (2) offices had a complete image backup of their hard disk.

- Very few (4) offices used VoIP for small time duration. They declared that this service was still unreliable and they did not have much information regarding its usage.

- Many (43) offices still used old ISDN Internet connection, although the prices of ADSL had fallen enough to be economically comparable to ISDN.

- Very few (3) offices developed their own Web site.

- Very few (8) offices used CRM programs for their daily operations.

- Still 3 offices used DOS-based professional applications.

- Many (79) offices used software packages' upgrade via post (receiving the upgrades in CD), while almost all software packages provided the ability of live update.

- Very few (2) offices begun to create electronic files of their customers' documents (paperless office).

Although there were also 2 open type questions, not many accountants made any suggestions. The following suggestions were made by some of them:
- Enable direct and complete interconnection between their software programs and the public e-services of Inland Revenue (www.taxisnet.gr) and Organisation of Social Security (www.ika.gr) without the need of typing again the same data in forms that exist on the these Web sites. Currently, this ability is provided for some services.

- Provide the possibility of sending the periodical statement VAT since the 1st statement electronically. Currently, a new customer should record in person his 1st statement to the Inland Revenue. Afterwards, he can send the 2nd and rest statements electronically.

- Provide the possibility of sending the liquidation statement VAT electronically via Internet. Currently, a pilot project offers this ability.

- Training on accounting software should be offered by the software companies not only in Athens (the capital of Greece) but also in the province.

Limitations of this study include the specific province and country sample of the accountant offices. A future study could cover all Greek regions as well other countries. A cross-country comparison could be interesting. Also, a cross-sector comparison with enterprises in other services' professions could be made. Nevertheless, it is hoped that the results of this study could provide an insight into the ICT and electronic services' usage by Greek accountants. These results could be a starting point for further research in this area.

\section{REFERENCES}

Anders, S. B., \& Fischer, C. M. (2004). A hard look at tax software: 2004 survey of New York State practitioners. The CPA Journal. Retrieved October 14, 2006, from: http://www.nysscpa.org/cpajournal/2004/704/i nfocus/p18.htm

Anderson, T., Fox, M., \& Schwartz, B. N. (2005). History and trends in e-filing: A survey of CPA practitioners. The CPA Journal. Retrieved October 14, 2006, from: http://www.nysscpa.org/cpajournal/2005/1005/ essentials/p66.htm

Bhansali, C. (2006a). The question every practicing accountant must ask. Accounting Technolog, June. Retrieved March 22, 2007, from: http://www.webcpa.com/ 
Bhansali, C. (2006b). A partial solution to a Daunting problem. Accounting Technology, September. Retrieved March 22, 2007, from: http://www.webcpa.com/

Bush, C. T. (2000). Accountants are thriving on the Web, says survey. Journal of Accountancy, 190 (5), 20, November. Retrieved November 23, 2006, from: http://www.aicpa.org/PUBS/JOFA/joaiss.htm

Chatzopoulos, K. C., \& Economides, A. A. (2009). A holistic evaluation of Greek municipalities' websites. Electronic Government, an International Journal (EG), 6(2), 193-212.

Czech Republic (2002). Technology used by enterprises. Retrieved October 11, 2006, from: http://www.czso.cz/eng/edicniplan.nsf/o/960204-2003-1_technology_used_by_enterprises

Economides, A. A., \& Terzis, V. (2008). Evaluating tax sites: An evaluation framework and its application. Electronic Government, an International Journal (EG), 5(3), 321-344.

Gallun, R. A., Heagy, C. D., \& Lindsey, H. C. (1993). How CPAs use computers. Journal of Accountancy, 175(1), 38-41, January.

Garen, K. (2006). Driving the firm of the future. Accounting Technology, June. Retrieved February 9, 2007, from: http://www.webcpa.com/

Gullkvist, B., \& Ylinen, M. (2005). Eaccounting systems use in Finnish accounting agencies. In Seppä M., Hannula M., Järvelin A-M., Kujala J.,Ruohonen M. and Tiainen T. (eds.) Frontiers of e-Business Research, Proceedings of the e-Business Research Forum 2005, Tampere, September 26-28, pp. 109117.

Johnston, R. P. (2005). A tour of tomorrow's technology. Journal of Accountancy, October. Retrieved November 23, 2006, from: http://www.aicpa.org/PUBS/JOFA/joaiss.htm

Khani, P. E., \& Zarowin, S. (1994). The technology used by high-tech CPAs. Journal of Accountancy, 177.

Levy, Y., Murphy, K. E., \& Zanakis, S. H. (2009). A value-satisfaction taxonomy of IS effectiveness (VSTISE): A case study of user satisfaction with IS and user-perceived value of IS. International Journal of Information Systems in the Service Sector, 1(1), 93-118.

Lexhagen, M. (2009). Customer perceived value of travel and tourism web sites. International Journal of Information Systems in the Service Sector, 1(1), 35-53.

Mintel International Group Ltd (2005). Retrieved October 14, 2006, from: http://www.mintel.com

OECD - Organization for Economic Cooperation and Development (2002). The OECD model survey of ICT usage in the business sector. Retrieved September 8, 2006, from: http://www.oecd.org

Pinhanez, C. (2009). A service science perspective on human-computer interface Issues of online service applications. International Journal of Information Systems in the Service Sector, 1(2), 17-35.

Prawitt, D., Romney, M., \& Zarowin, S. (1997). A journal survey: the software CPAs use. Journal of Accountancy. Retrieved November 23, 2006, from: http://www.aicpa.org/PUBS/JOFA/joaiss.htm

Roxas, M. L., Peek, L., Peek, G., \& Hagemann, T. (2000). A preliminary evaluation of professional accounting services: Direct marketing on the Internet. Journal of Services Marketing, 14(7), 595-605.

Terpsiadou, M. H. \& Economides, A. A. (2009). The use of information systems in the Greek public financial services: The case of TAXIS. Government Information Quarterly, in press.

The Greek Social Security Organization (IKA). http://www.ika.gr

The Inland Revenue Service (TAXIS NET). http://www.taxisnet.gr/web/default.html

Voiculescu, A. (2000). Strategic Implications of Electronic Commerce for UK businesses. Retrieved October 14, 2006, from: http://www.aurelvoiculescu.com/

Zarowin, S. (2003). Hot stuff: what you need and what you don't: your technology setup 
may be sufficient for your needs accountants. Journal of Accountancy, 195. Retrieved November 23, 2006, from: http://www.aicpa.org/PUBS/JOFA/joaiss.htm

Zarowin, S. (2006). Rate Yourself in the Paperless Race. American Institute of Certified Public Accountant. Journal of Accountancy.
May. Retrieved February 17, 2007, from: http://www.aicpa.org/PUBS/JOFA/joaiss.htm

Zarowin, S. (2004). Top tools for CPAs. Journal of Accountancy. May4. Retrieved November 23, 2006, from: http://www.aicpa.org/PUBS/JOFA/joaiss.htm 


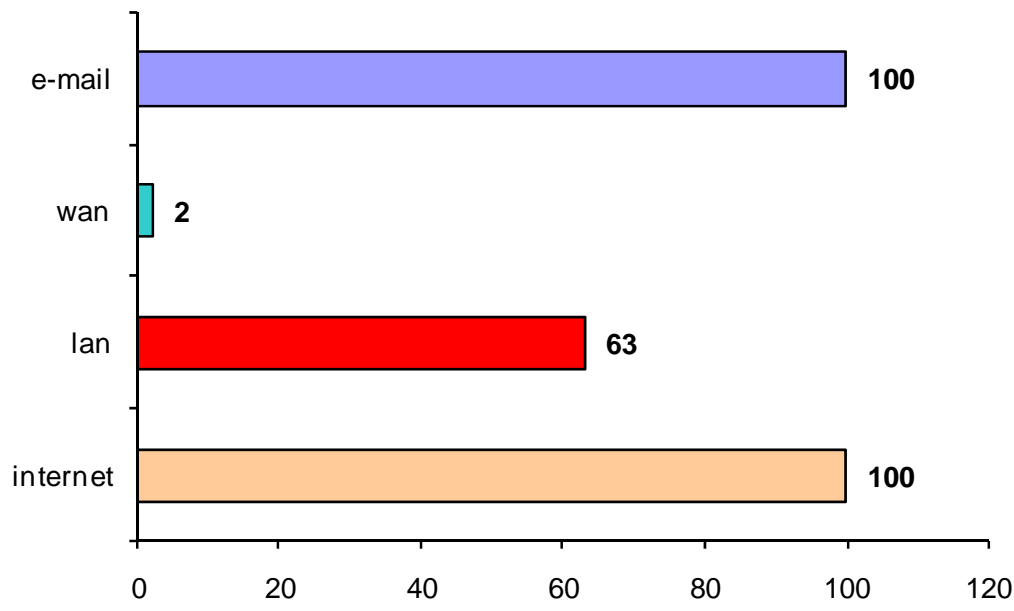

Figure 1: ICT usage 


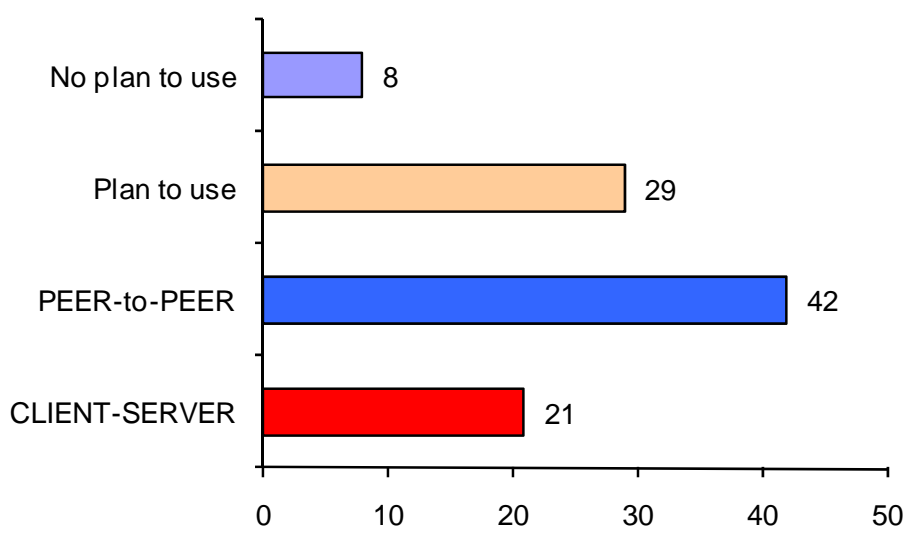

Figure 2: LAN types and plans to use LANs 


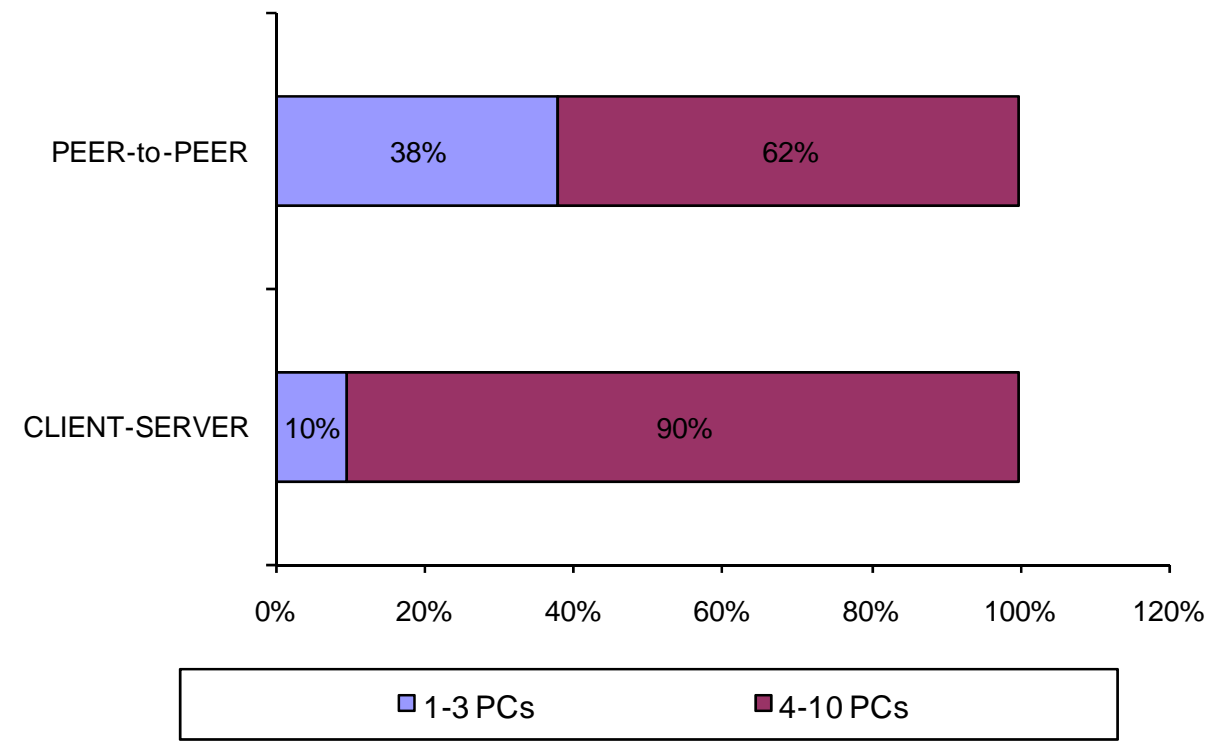

Figure 3: Relationship between "LAN type" and "Number of PCs" 


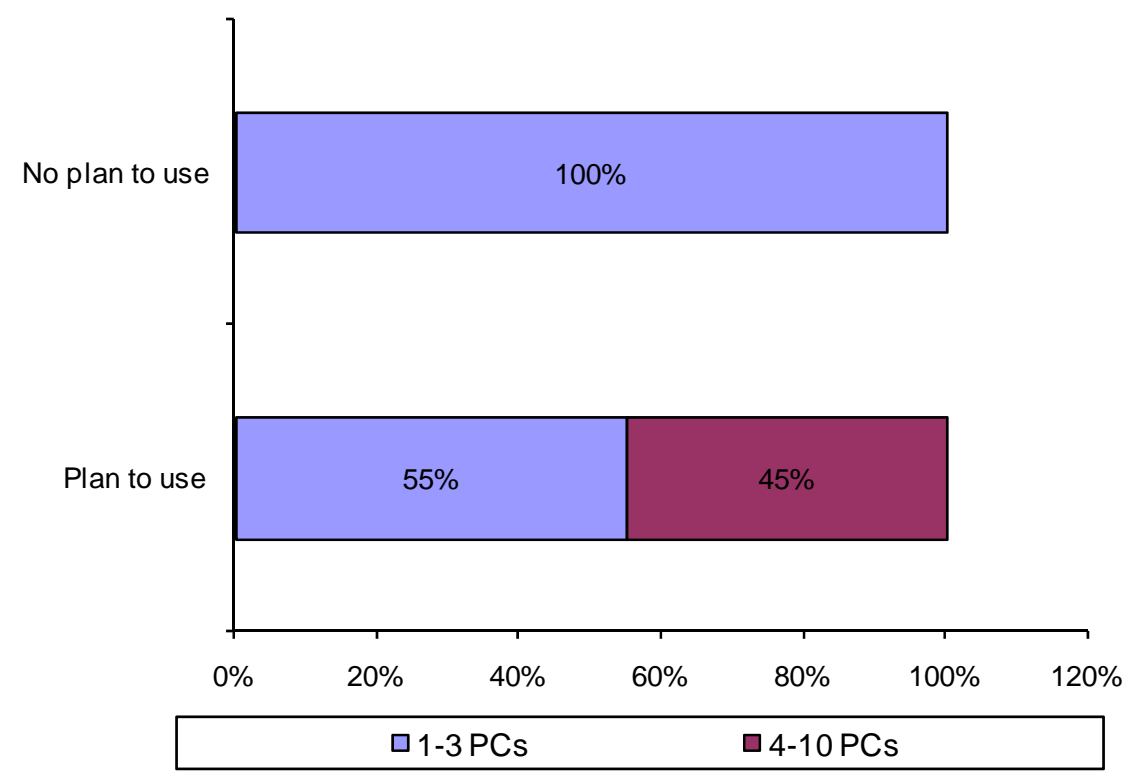

Figure 4: Relationship between the "Plans for LANs" and "Number of PCs" 


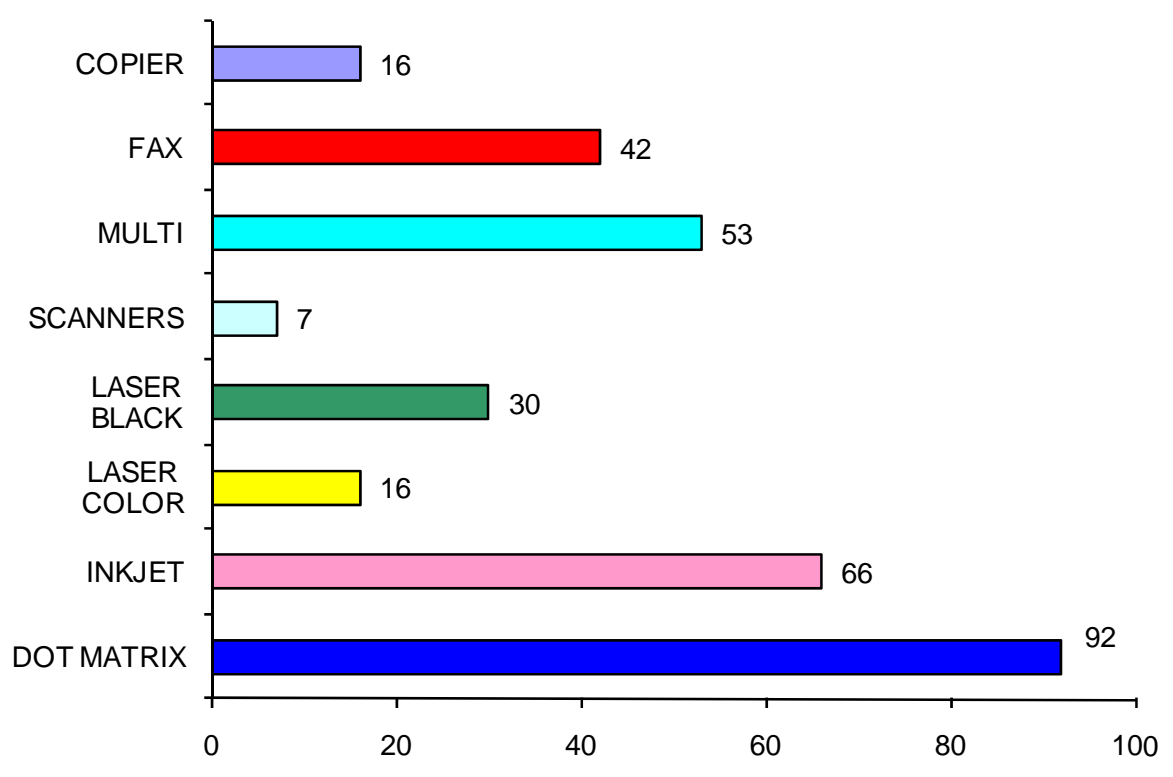

Figure 5: Printers usage 


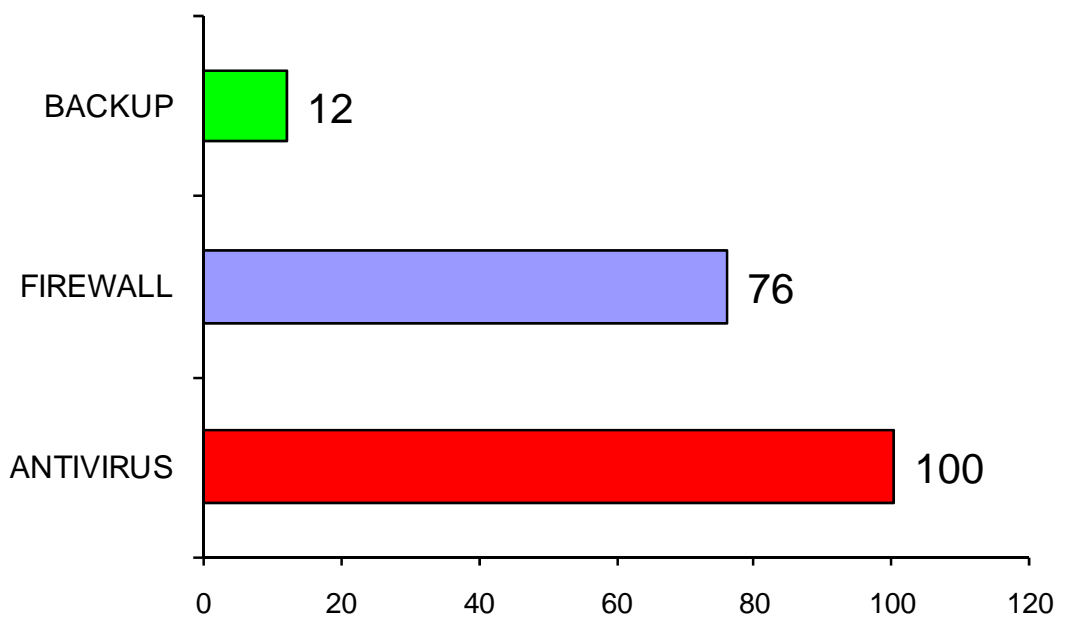

Figure 6: Security protection mechanisms. 


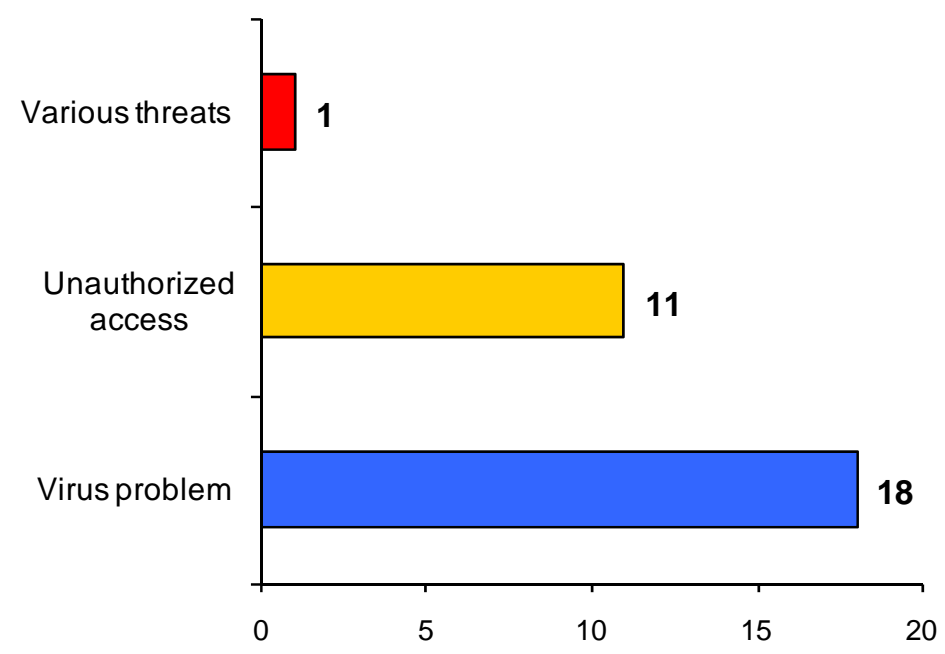

Figure 7: Security problems. 


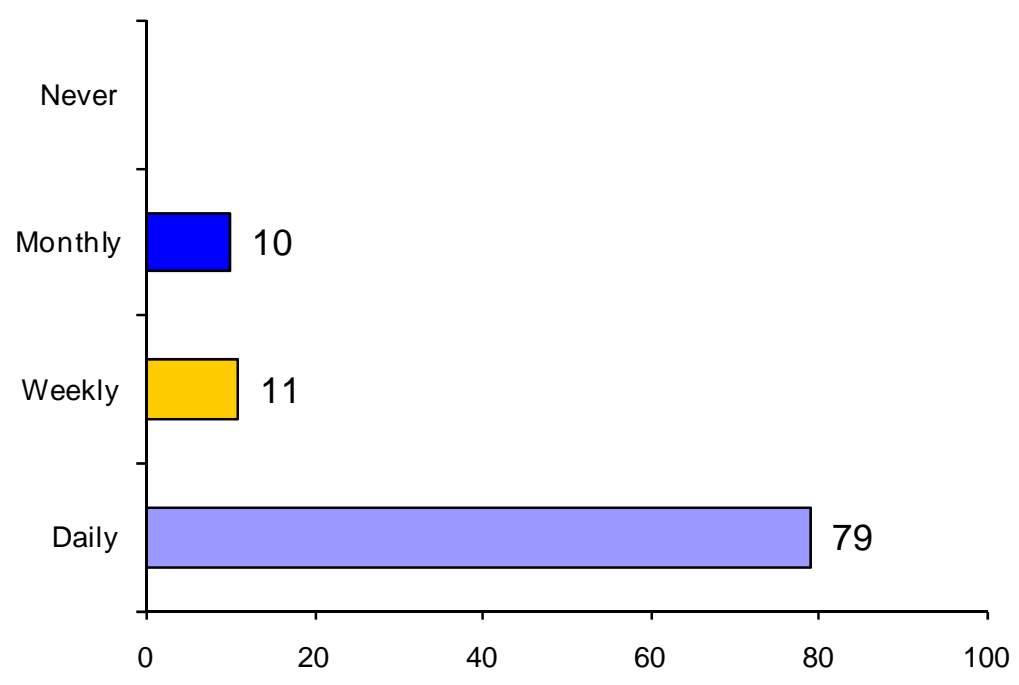

Figure 8: Backup frequency 


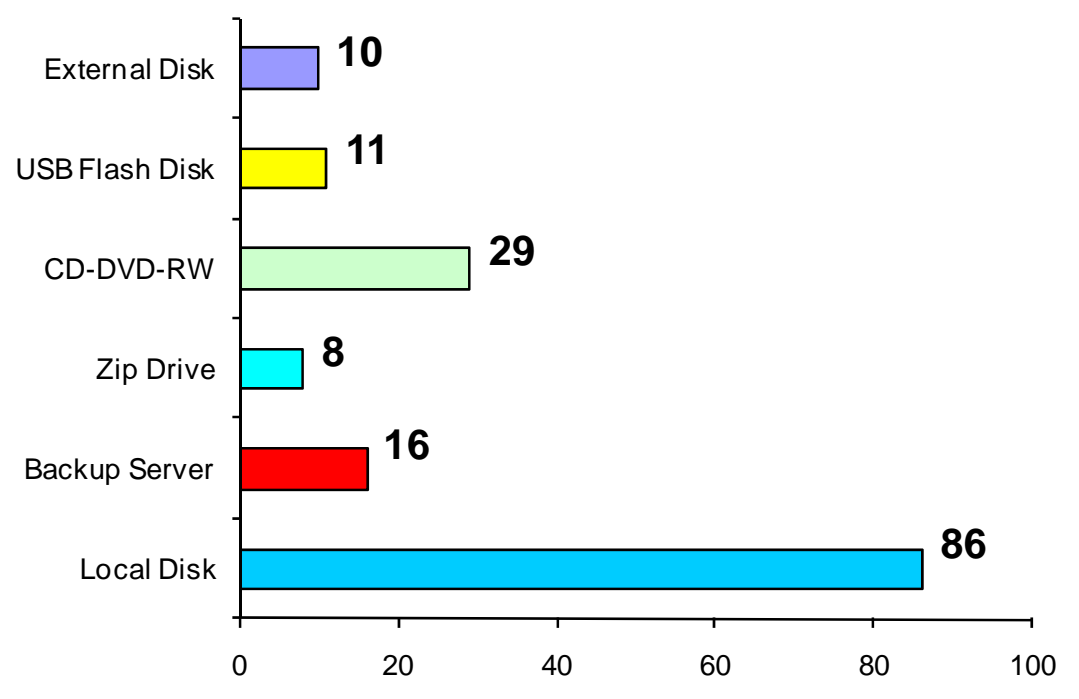

Figure 9: Data media backup 


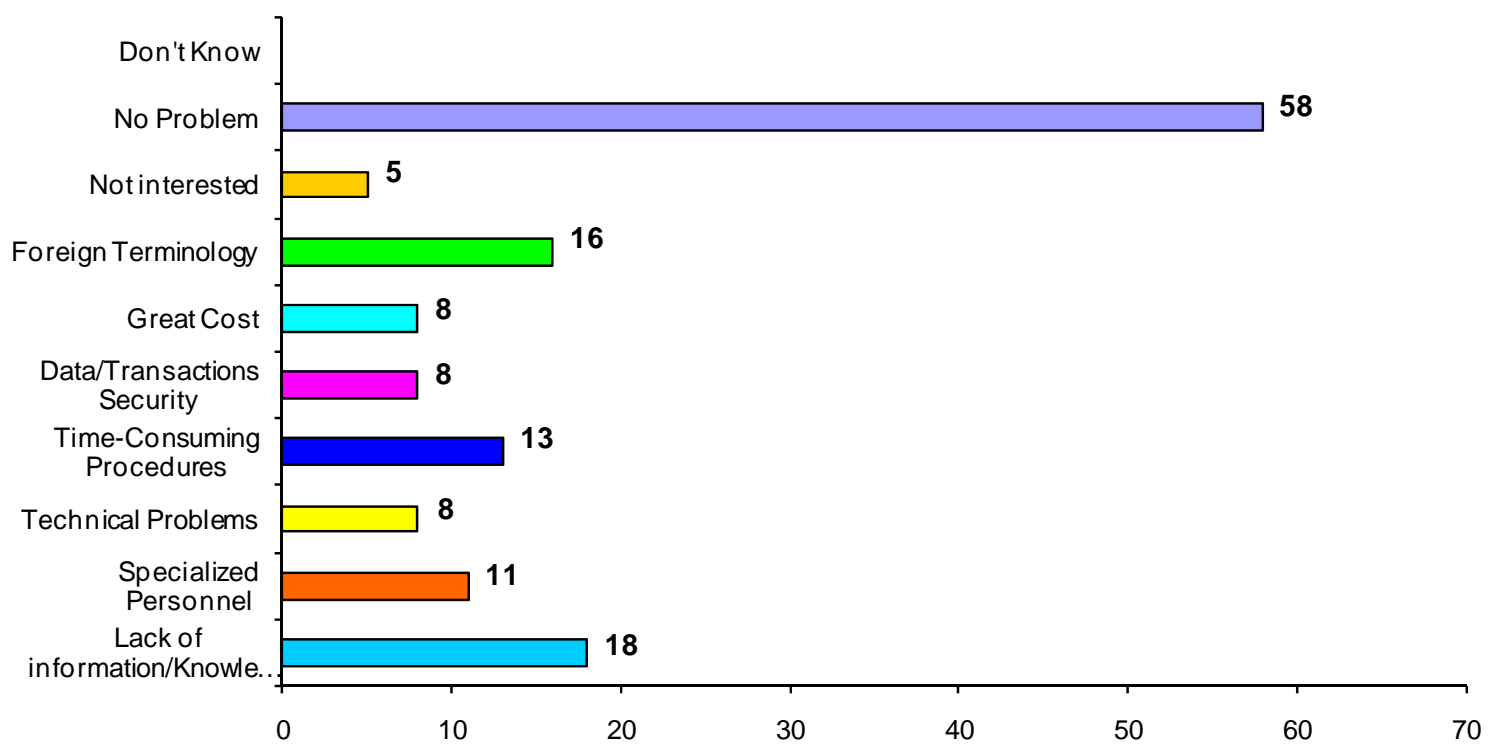

Figure 10: ICT Problems 


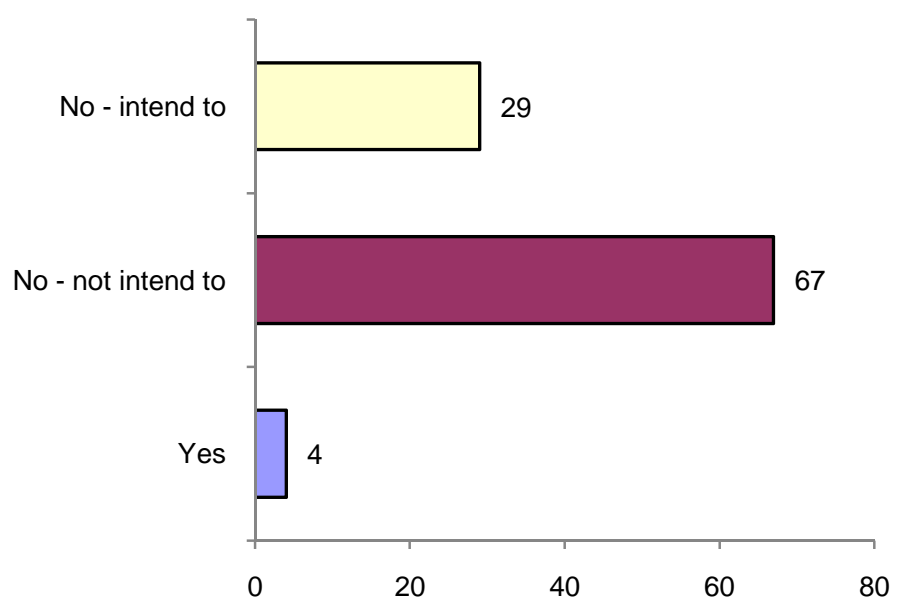

Figure 11: VoIP usage 


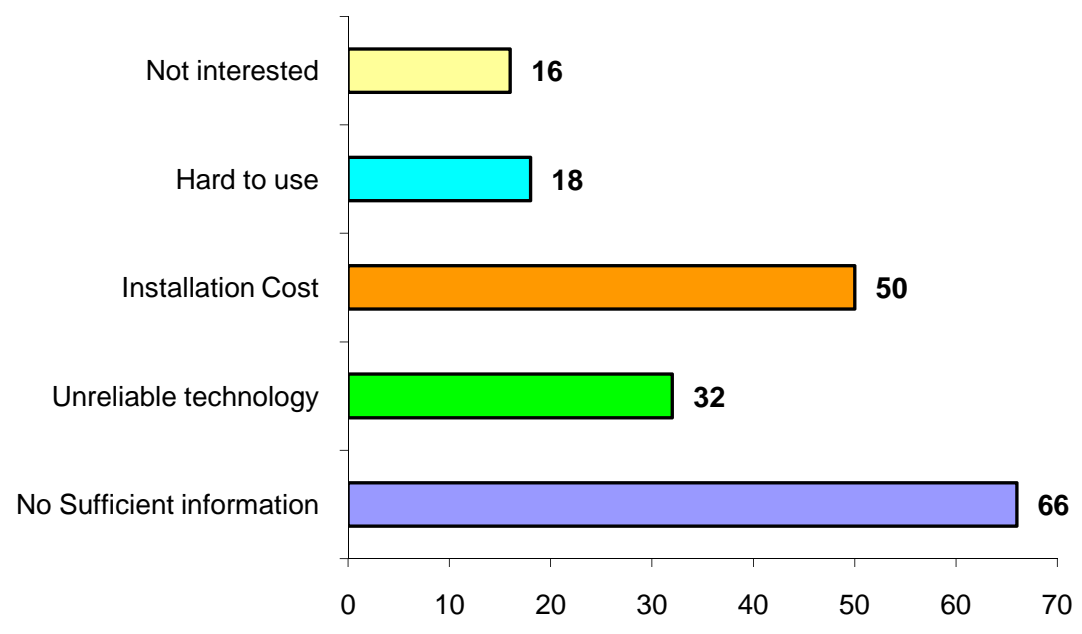

Figure 12: Reasons for not using VoIP 


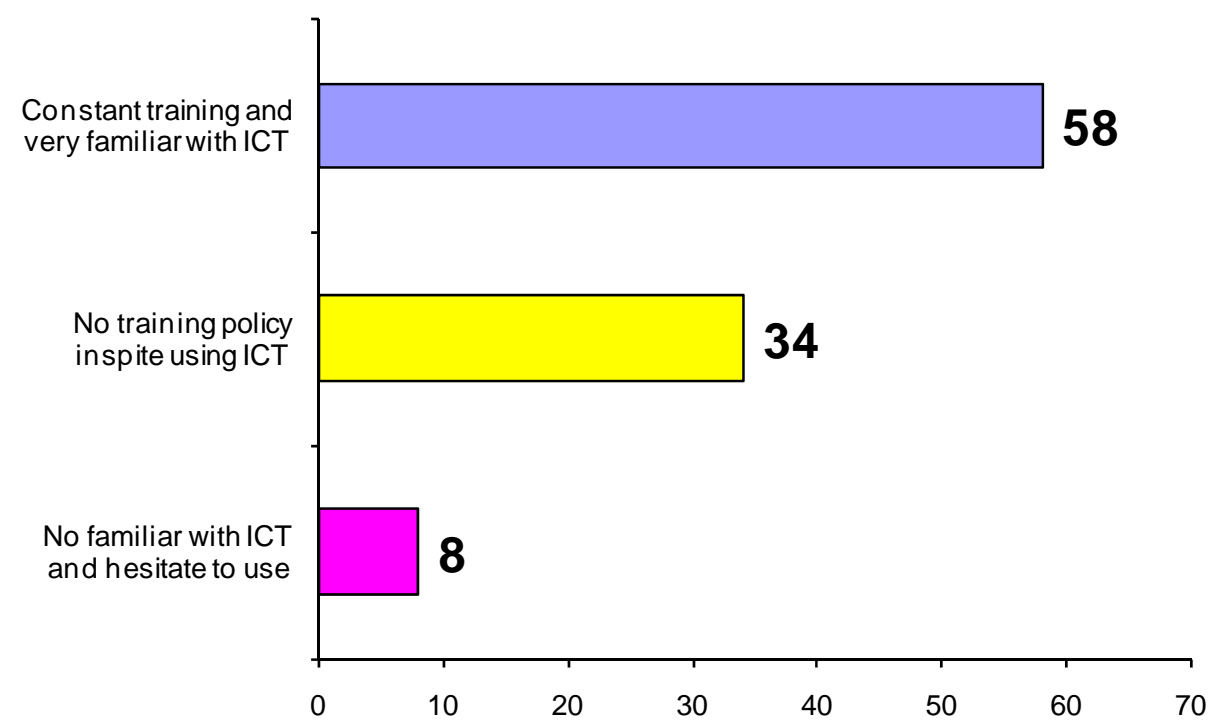

Figure 13: ICT familiarity and training policy 


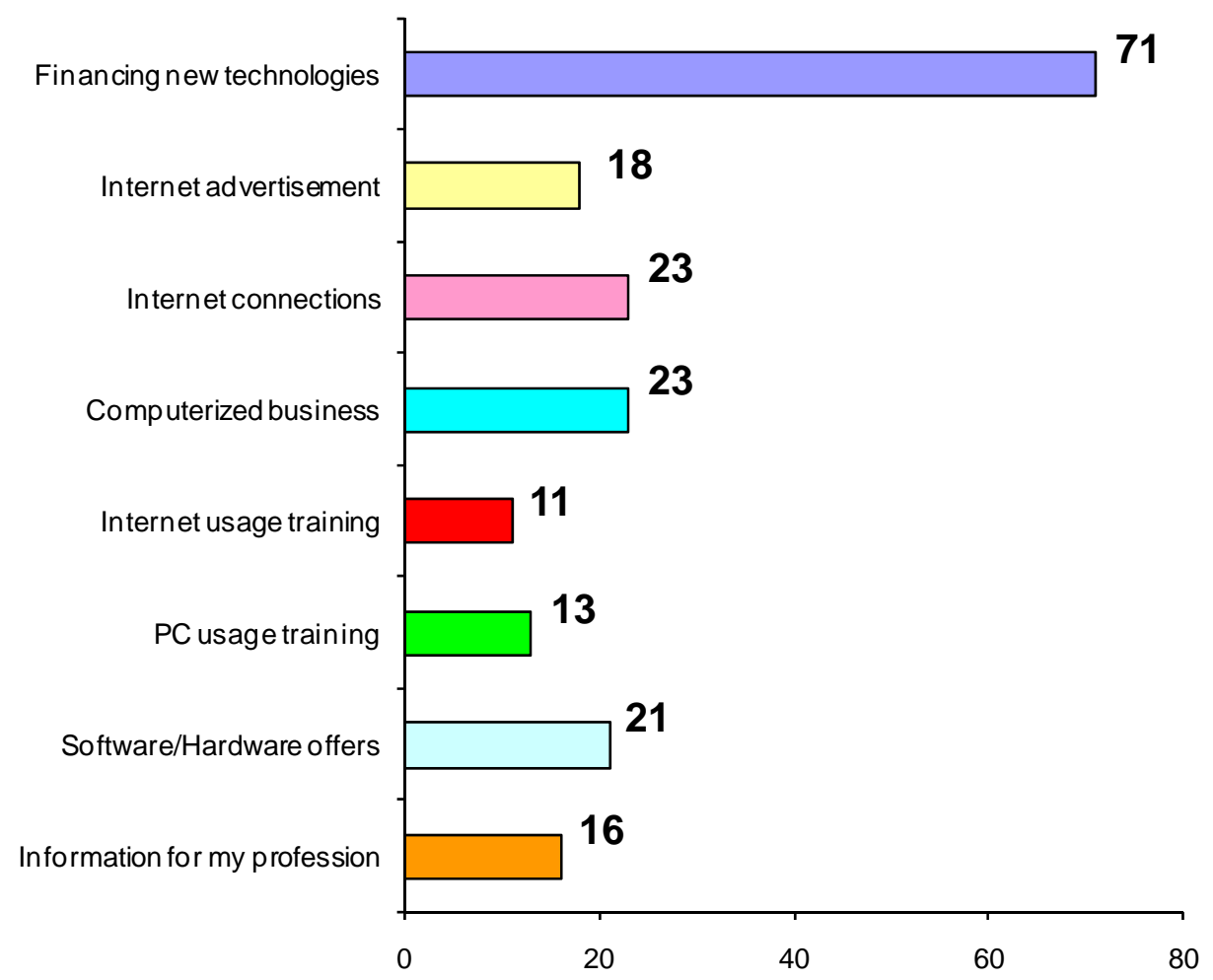

Figure 14: What accountants want from Government and Chamber 


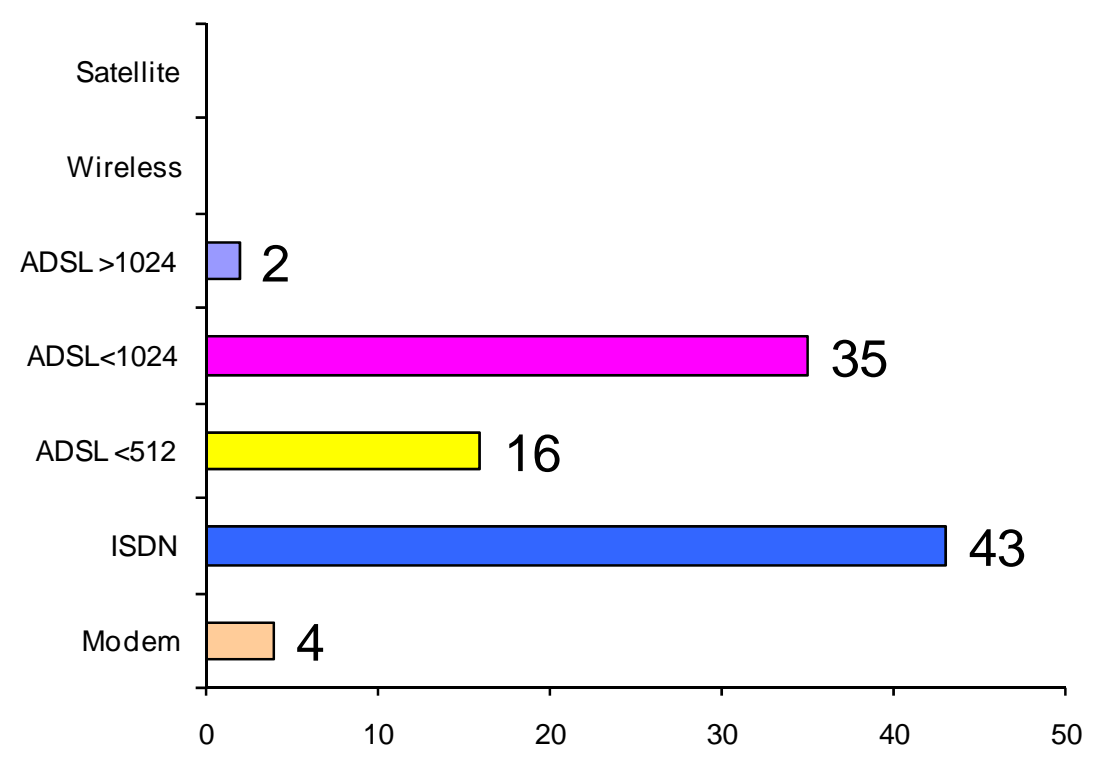

Figure 15: Internet connection type 


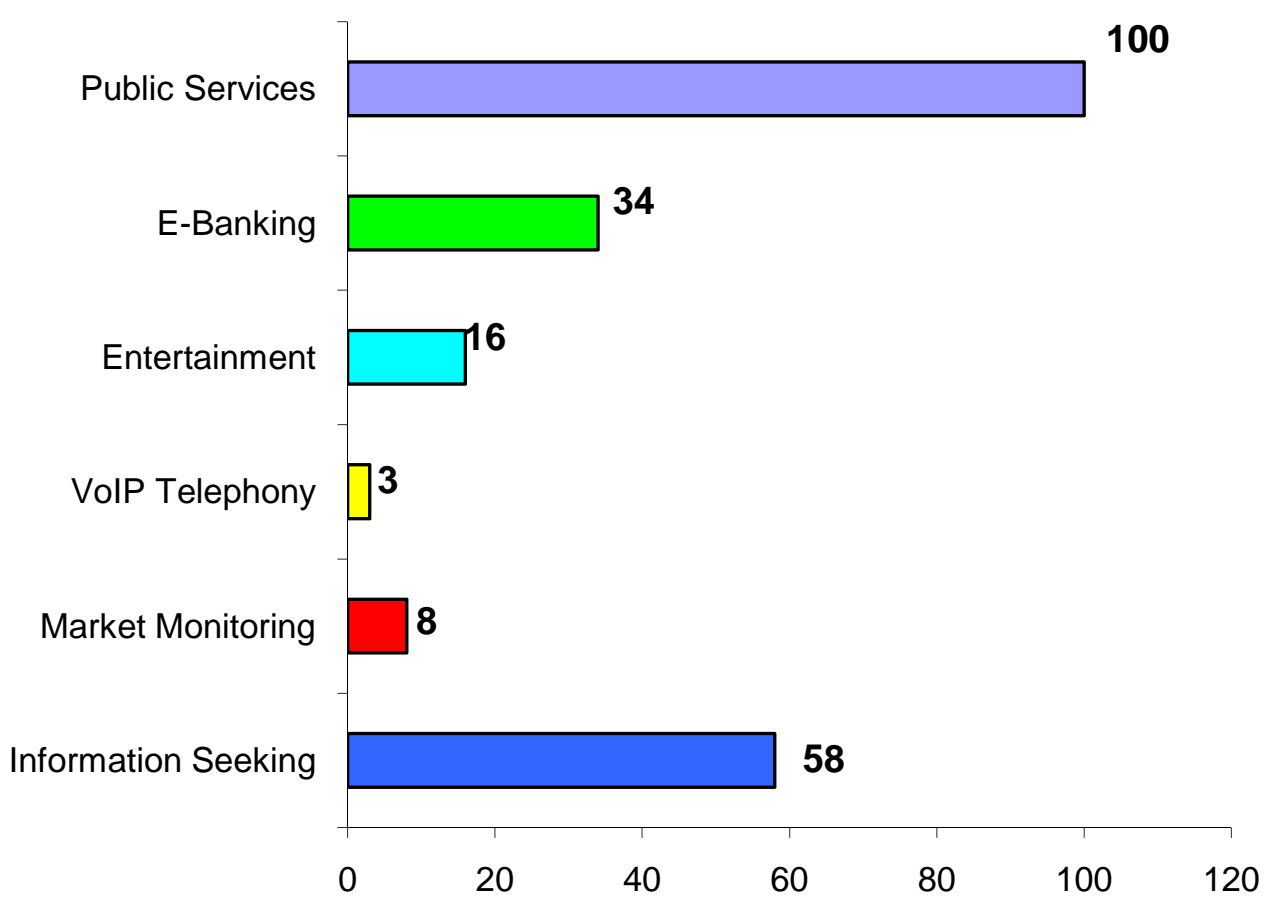

Figure 16: Internet usage reasons 


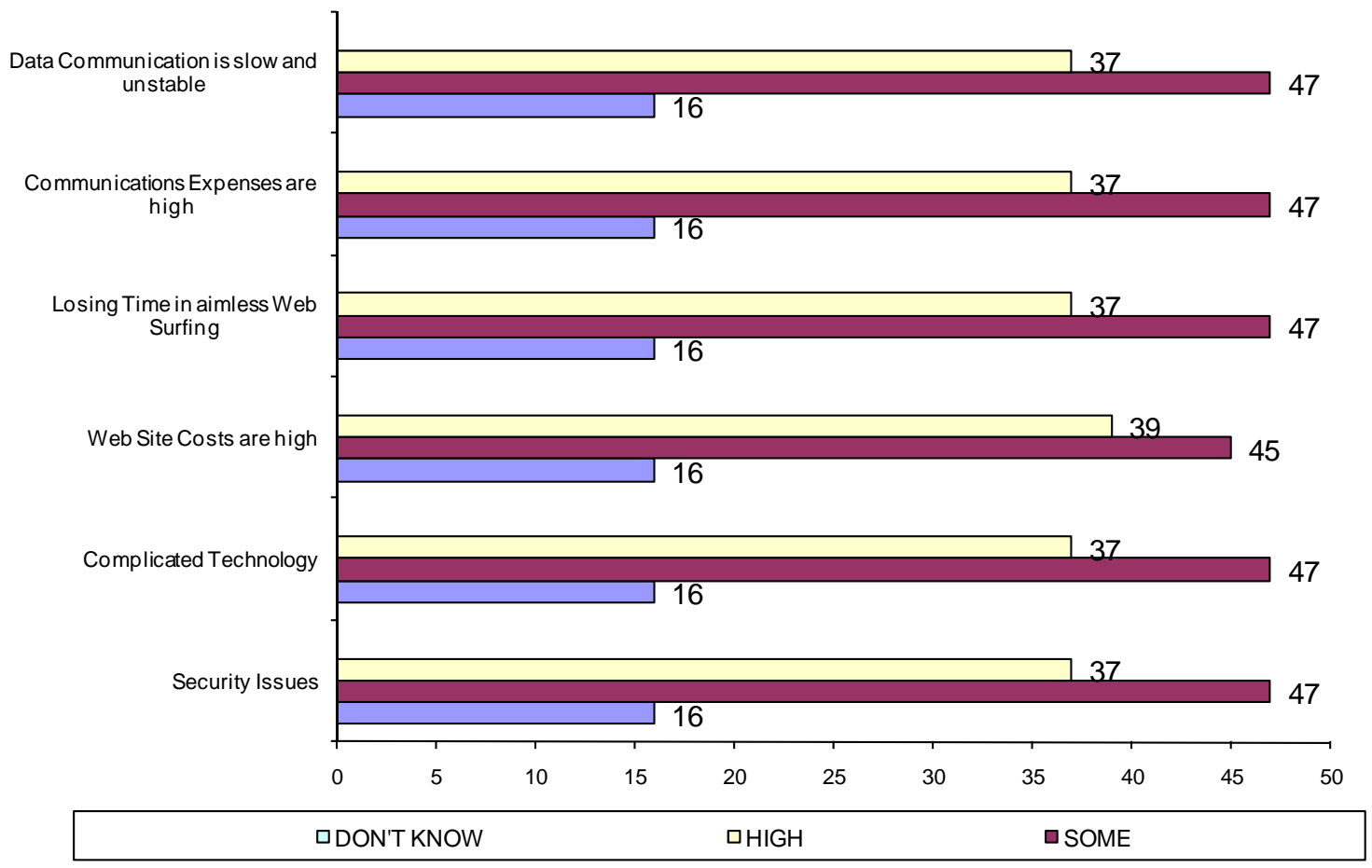

Figure 17: Internet problems evaluation 


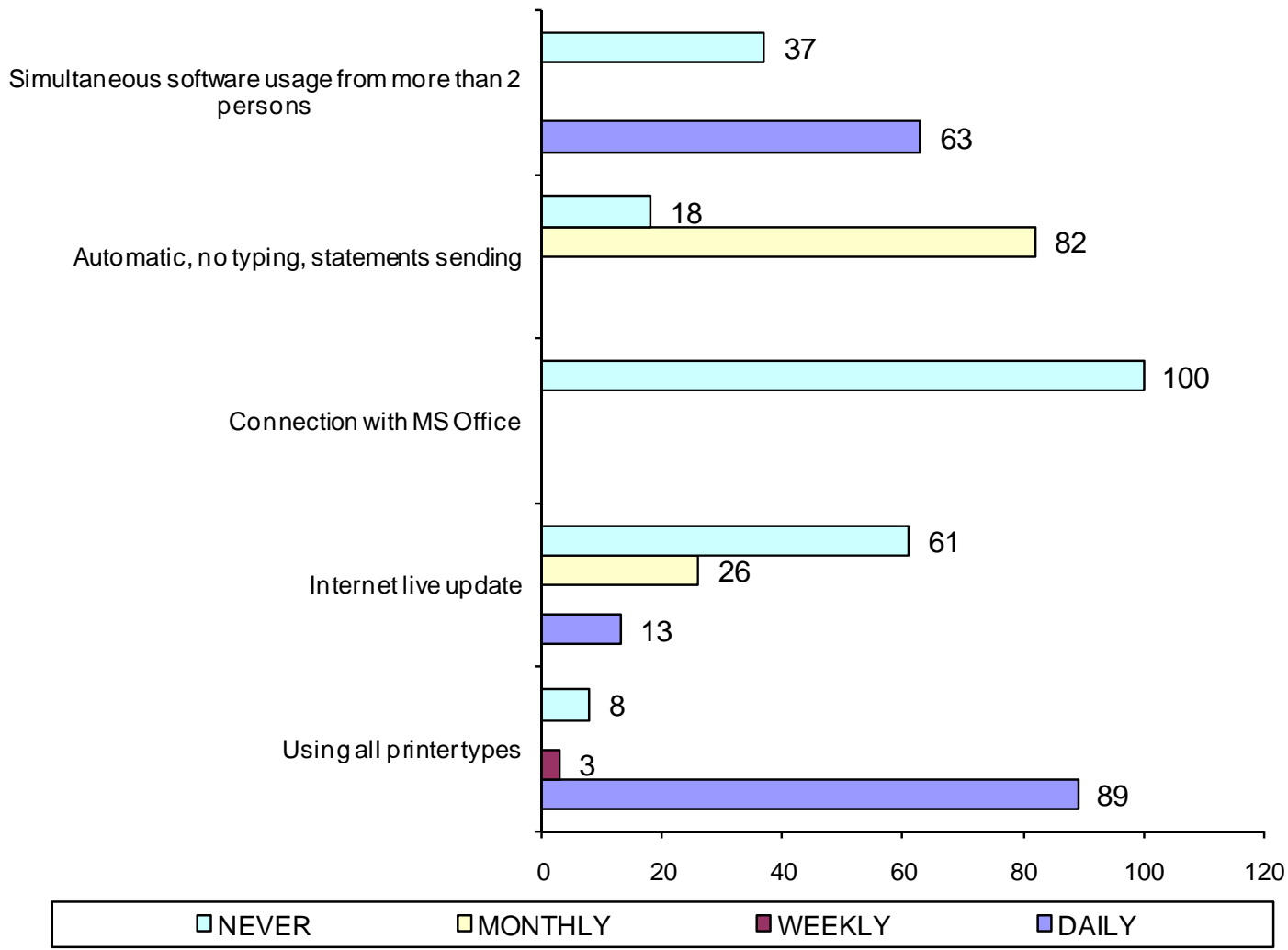

Figure 18: A’ \& B’ Books Category Services usage 


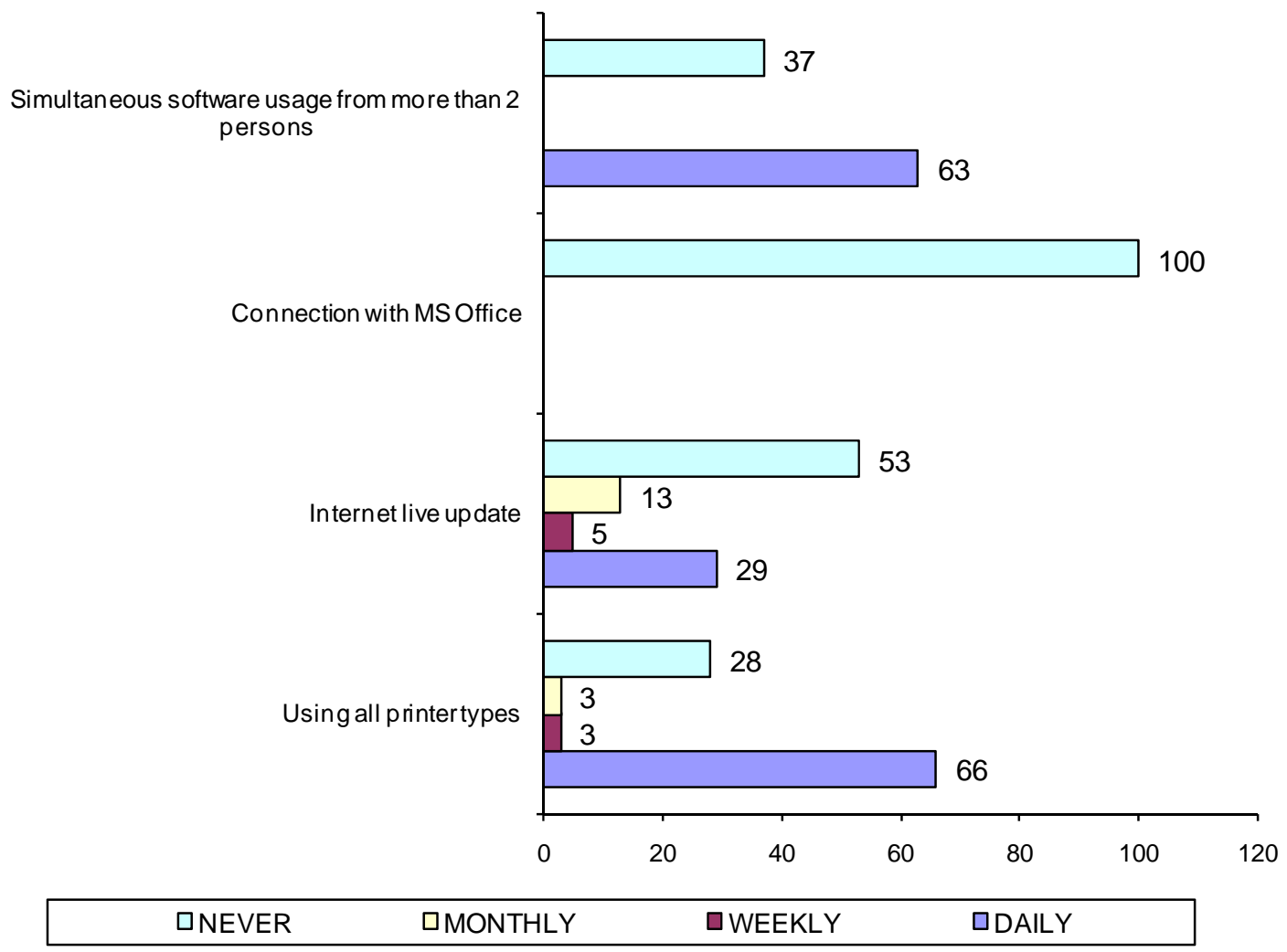

Figure 19: C’ Books Category Services usage 


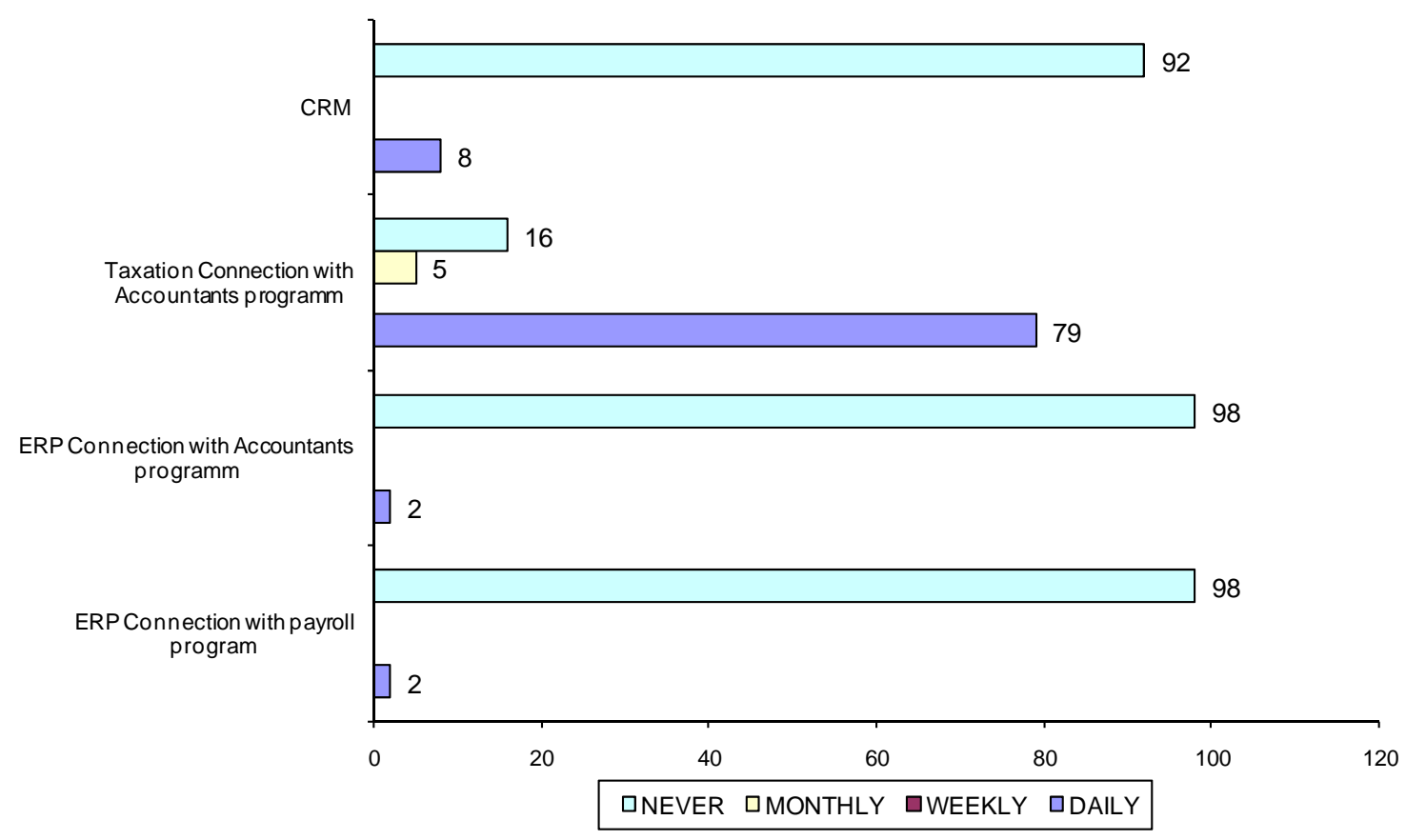

Figure 20: ERP, taxation software and CRM Services usage 


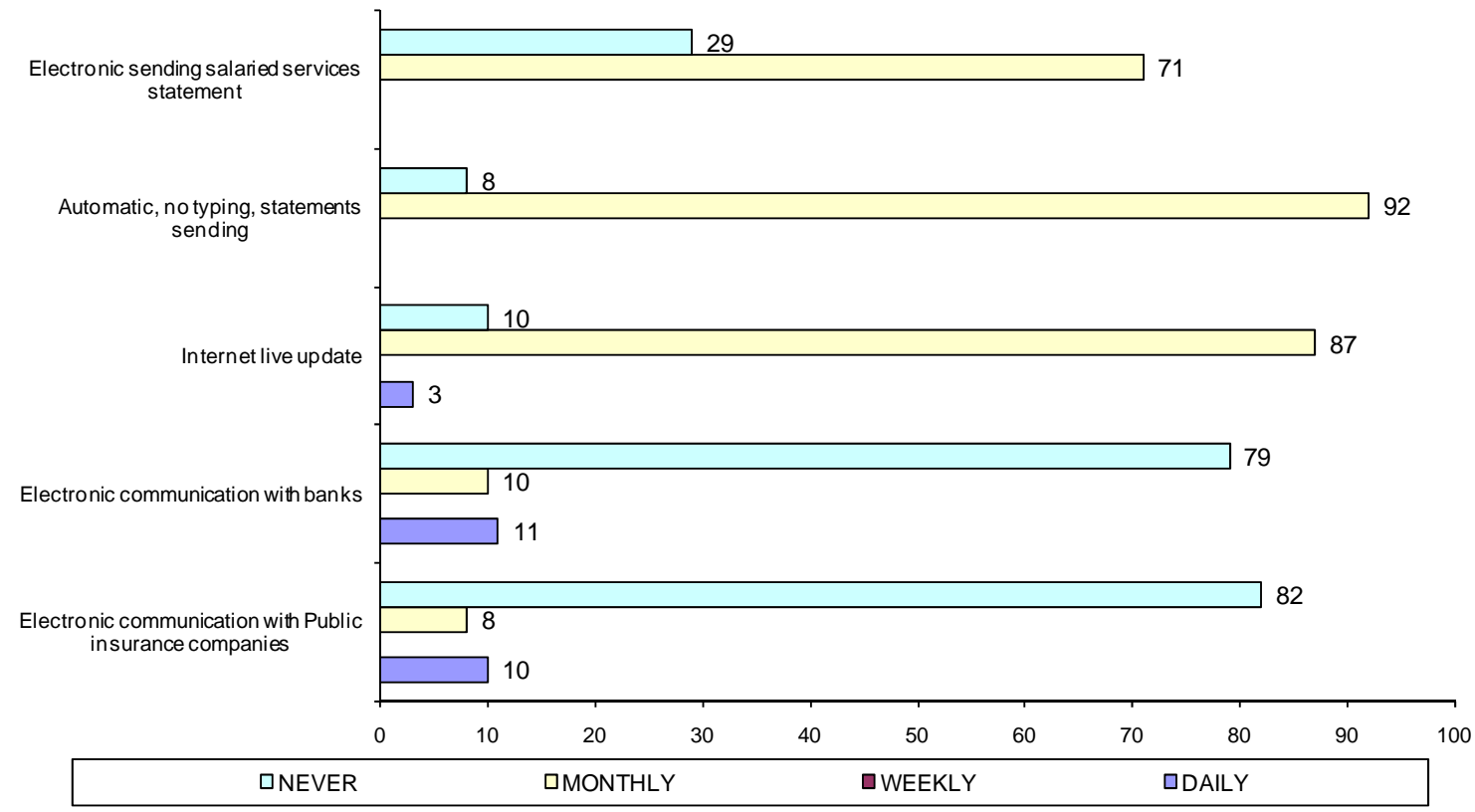

Figure 21: Payroll Services usage 


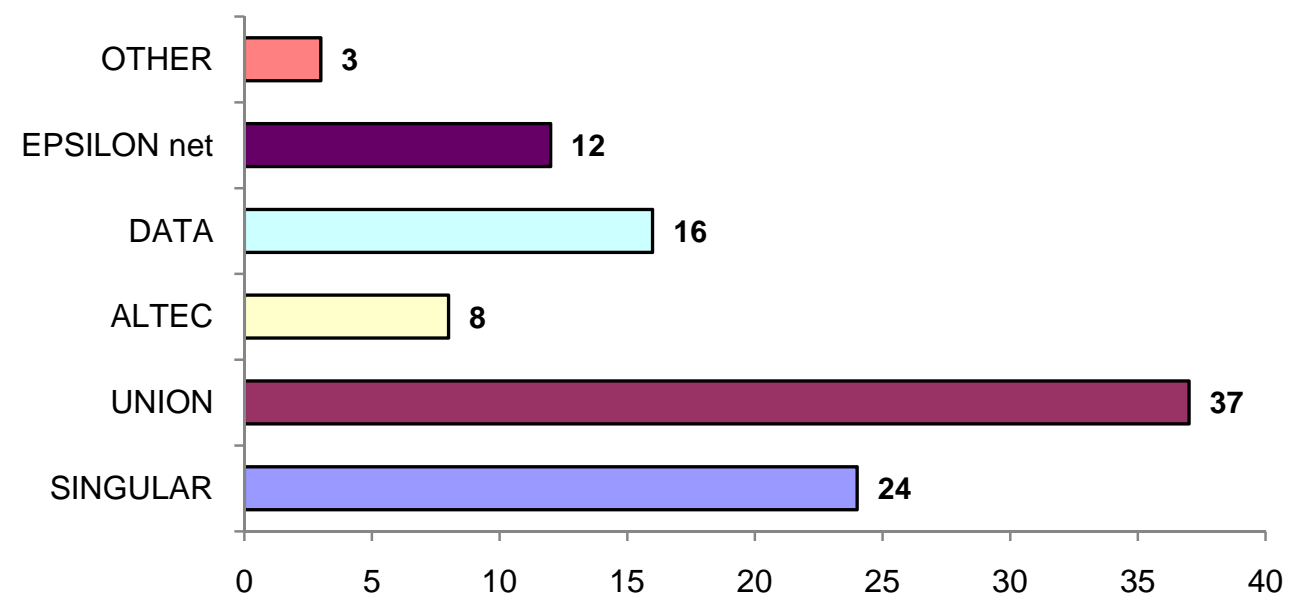

Figure 22: Program's brands that accountants use 


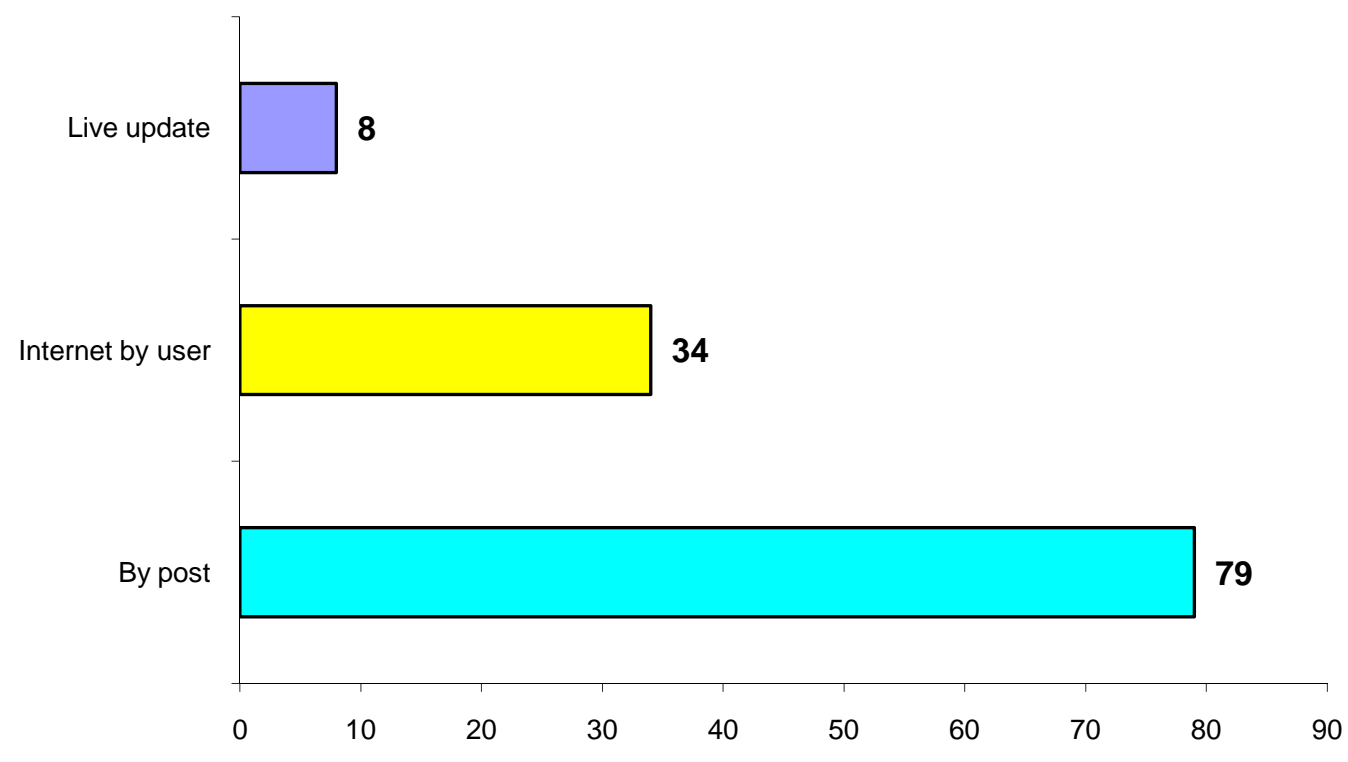

Figure 23: Program’s update 


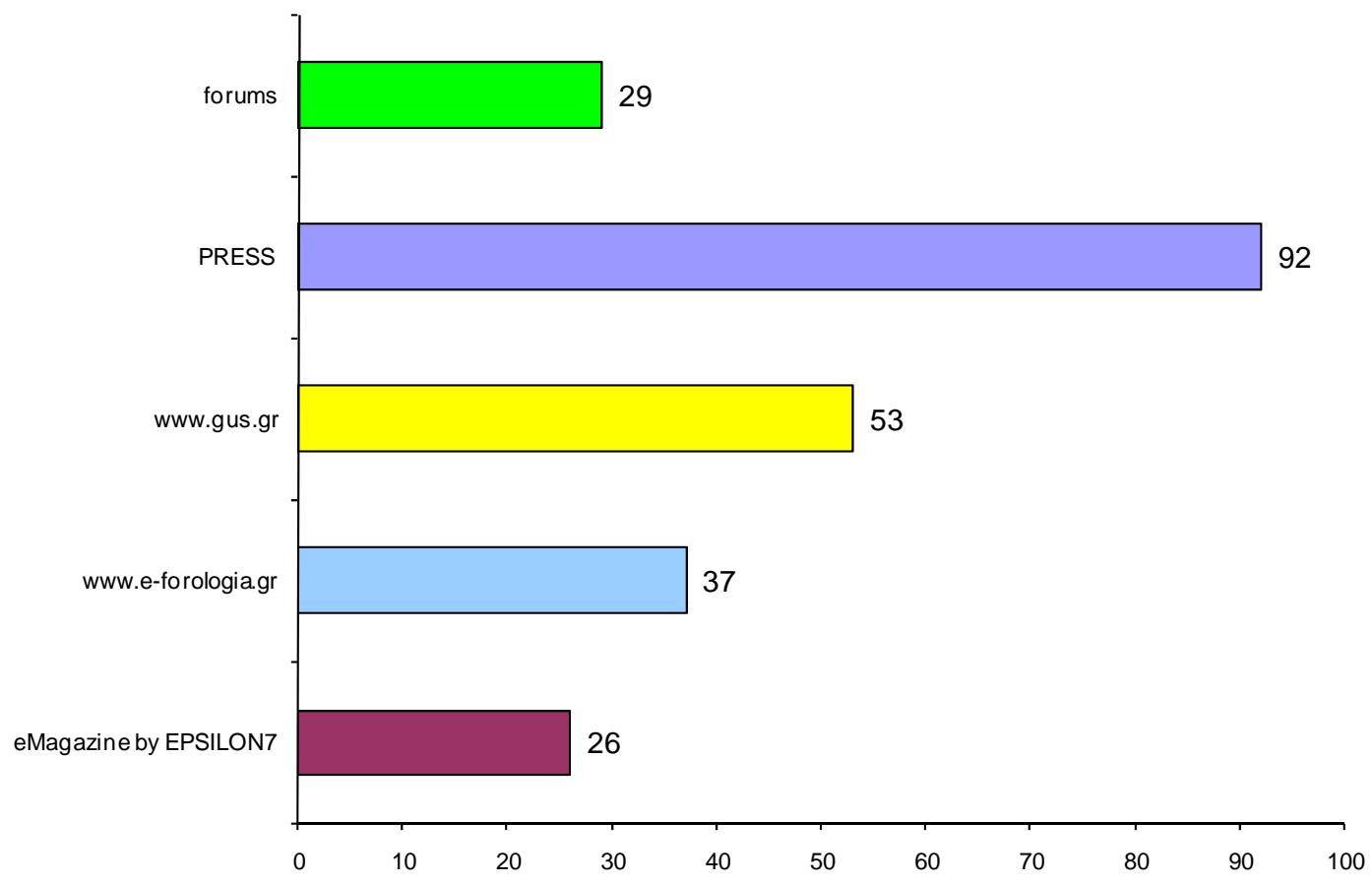

Figure 24: Frequent profession’s informing 


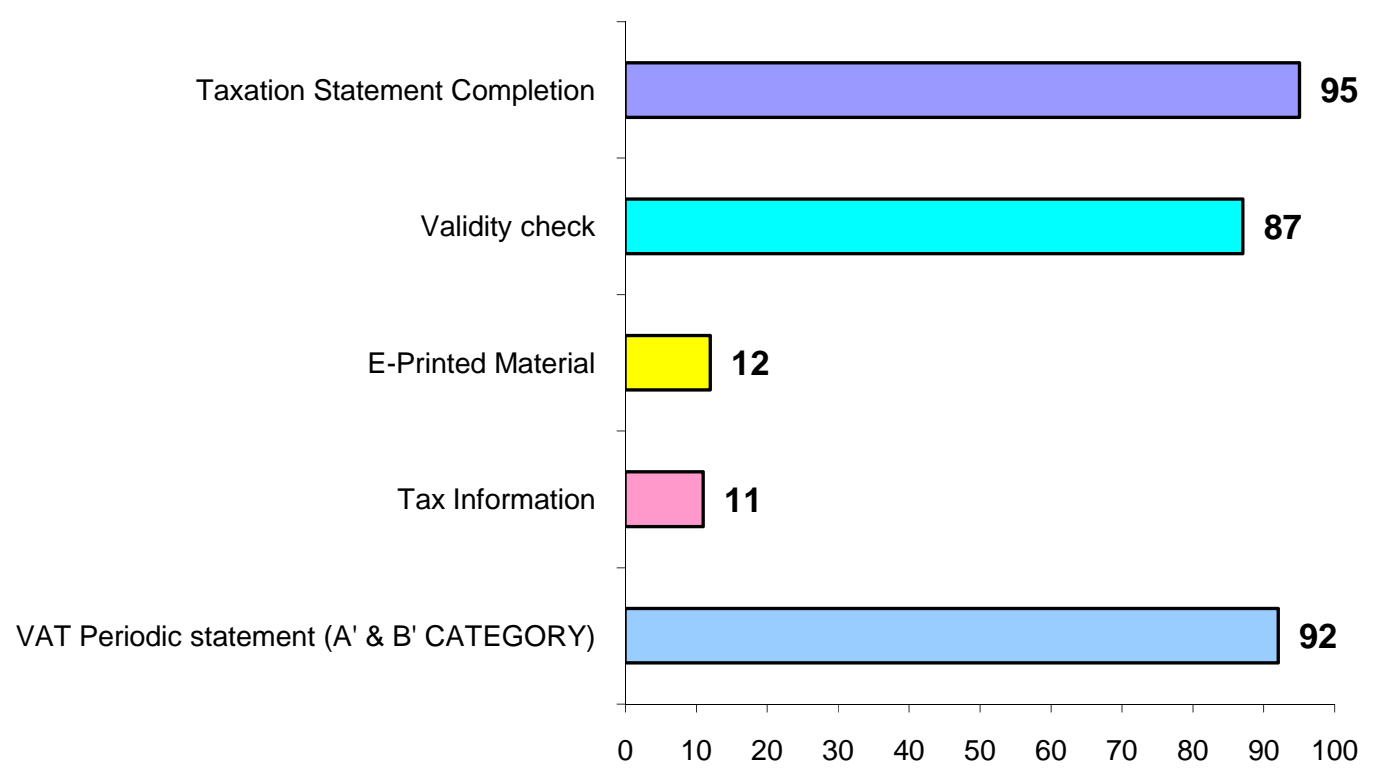

Figure 25: Greek government services (TAXIS NET) usage 


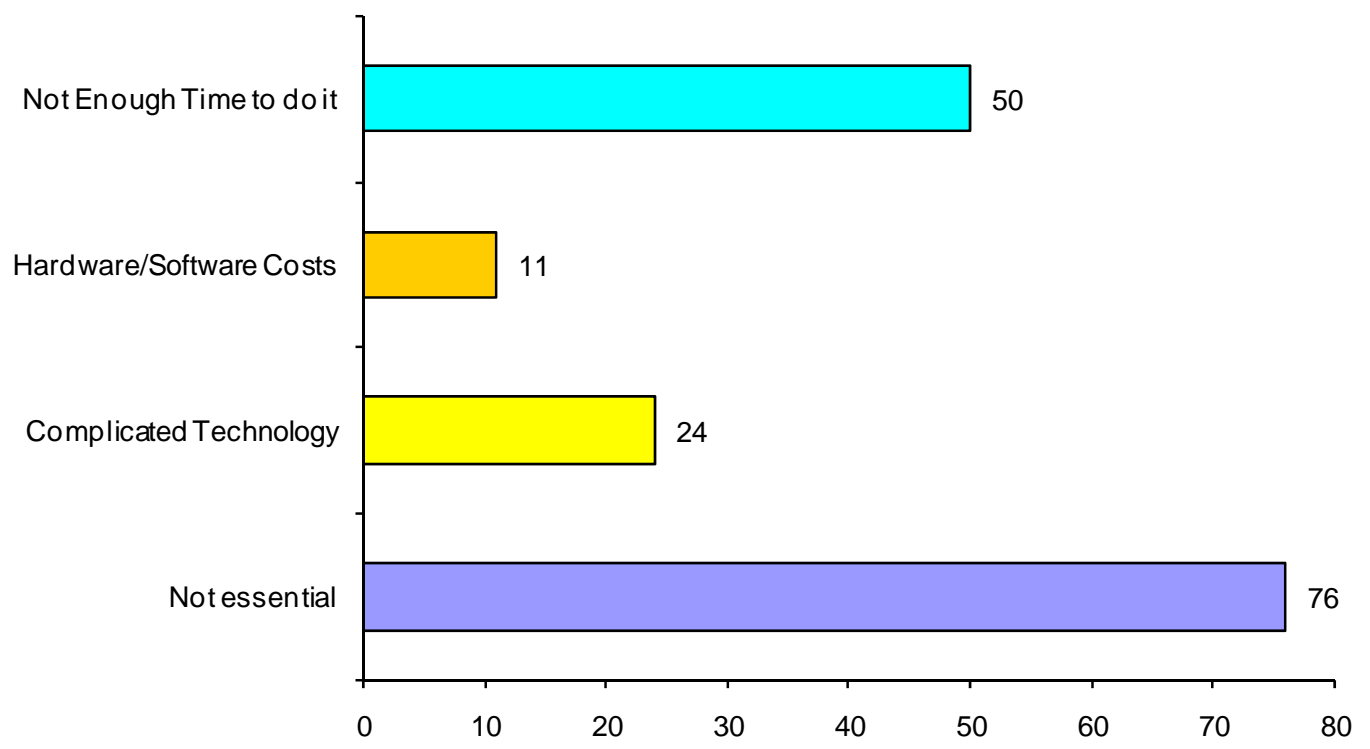

Figure 26: Reasons of not using "paperless Office” 


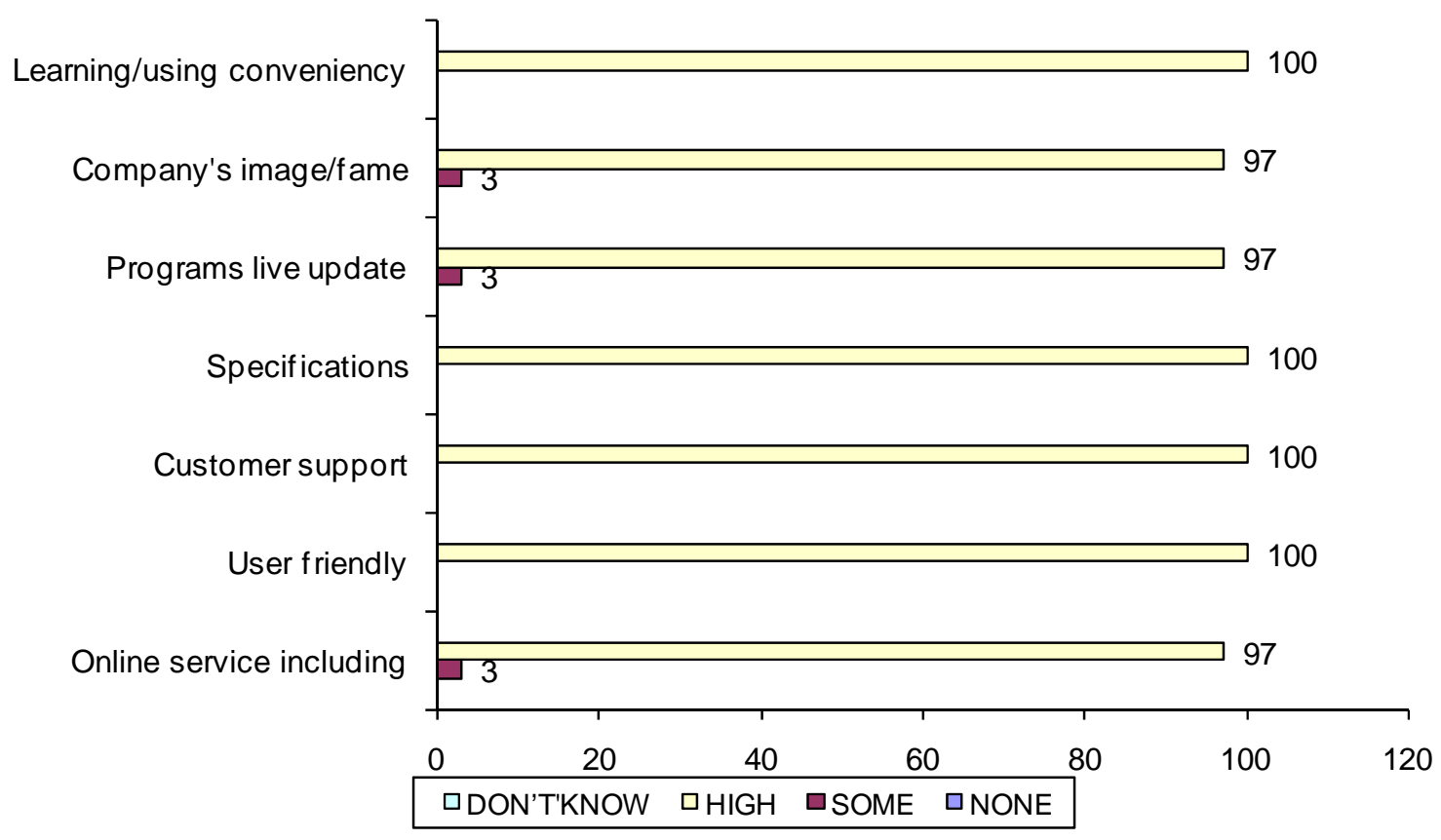

Figure 27: Software evaluation criteria 